\title{
Türkiye'de Siyasi Partilerin Yerel Katılım Politikaları
}

\section{Local Participation Politics of Political Parties in Turkey}

\author{
Dr. Öğr. Üyesi Sinan GÜRCÜOĞLU (iD) 1
}

\begin{abstract}
$\ddot{O} z$
Demokrasi, ortaya çıkışından günümüze dek çok farklı kavramlarla tanımlanmaya çalışılmıştır. Bunlar içinde en kabul göreni, siyasal bir rejim olduğu ve esas itibariyle yönetilen kitlenin kararlara katılarak kendi kendini yönetmesi olmuştur. Eski çağlarda yönetilenlerin kararlara doğrudan katılımı söz konusu iken günümüzde, teknolojiden nüfus artışına, devletlerin büyüklüğünden örgütsel yapıların değişimine kadar çok farklı nedenler genel ölçekte halkın yönetime doğrudan katılımına imkân vermemektedir. Ancak buna karşın demokratik yönetimlerde halkın yönetime katılma taleplerini karşılamak üzere yerel örgütlenmelerde uygun bir model olarak katılımcı demokrasi modeli benimsenmektedir. Demokrasinin vazgeçilmez unsurları olarak görülebilen siyasi partiler ise halkın yönetime katılma taleplerini en iyi şekilde karşlamak üzere çeşitli politikalar üretmekte, seçim öncesi konuya ilişkin vaatlerde bulunmakta ve seçilmeleri durumunda neler yapacaklarını halka duyurmaktadırlar. Bu çalışmanın amacı Türkiye'deki siyasi partilerin yerel seçimler öncesi yerel demokrasi bağlamında ortaya koydukları ve seçilmeleri durumunda hayata geçirmeyi vaat ettikleri politikaları karşılaştırmalı olarak analiz etmektir. Araştırmanın evrenini; Türkiye'de 2014 ve 2019 yll içinde gerçekleştirilen yerel seçimlere katılan siyasi partiler oluşturmaktadır. Örneklemini ise bu seçimlerde en yüksek oyu alan 5 siyasi parti oluşturmaktadır. Araştırmada, nitel yöntemlerden betimsel yöntem tercih edilmiş, doküman incelemesi tekniği kullanılarak siyasi partilerin yerel seçim bildirgeleri/beyannameleri/manifestoları incelenmiş ve konuya ilişkin veriler elde edilmiştir. Yerel katılımın siyasi partilerce önemli bir politika olarak görüldüğü ve seçim öncesi vaatlerde çeşitli düzeylerde yer verildiği görülmüştür.
\end{abstract}

Anahtar Kelimeler: Yerel katılım, yerel demokrasi, kamu politikası, yerel katılım politikaları

Makale Türü: Araştırma

\begin{abstract}
Democracy has been tried to be defined with many different concepts since its emergence. The most accepted among these was that it was a political regime and that the self-directed mass of the principally managed group was self-directed. While there is a direct involvement of the rulers in the ages in the past, many different reasons, from technology to population growth, from the size of the states to the change of organizational structures, do not allow the direct participation of the people in the administration on a general scale. However, in democratic governments, participatory democracy model is adopted as an appropriate model in local organizations to meet the demands of the people to participate in the administration. Political parties, which can be seen as indispensable elements of democracy, produce various policies in order to best meet the demands of the public to participate in the administration, make promises about the issue before the elections and announce what they will do if they are elected. The purpose of this study; before the local elections of political parties in Turkey put forward in the context of local democracy and the policies they promised to implement if elected it is to analyze comparatively. The universe of the research; Turkey is the political parties who participated in the local elections held in 2014 and 2019. The sample consists of 5 political parties with the highest votes in these elections. In the research, descriptive method was preferred from qualitative methods, local election declarations / manifestos of political parties were examined by using document analysis technique and data on the subject were obtained. It has been observed that local participation is seen as an important policy by political parties and various levels of pre-election promises.
\end{abstract}

\footnotetext{
${ }^{1}$ Uşak Üniversitesi, Adalet MYO, sinan.gurcuoglu@usak.edu.tr.
}

Atıf için (to cite): Gürcüoğlu, S. (2020). Türkiye'de siyasi partilerin yerel katilim politikaları. Afyon Kocatepe Üniversitesi Sosyal Bilimler Dergisi, 22(4), 1046-1066. 
Keywords: Local participation, local democracy, public policy, local participation policies

Paper Type: Research

\section{Giriș}

Eski Yunancada halkın iradesi anlamına gelen demokrasi, halkın kendi kendini yönetmesini ifade etmekte ve halk iradesinin yönetime üst düzeyde yansımasına imkân sunan bir devlet ya da hükümet sistemi olarak kabul edilmektedir. Doğuşundan günümüze kadar olan süreçte demokrasinin anlamı ve algılanışı büyük değişikliğe uğramıştır. Temel esasları saklı kalmak kaydıyla bulunduğu çağın gereklerine uygun olarak farklı şekillerde yorumlanmış ve yeniden tanımlanmıştır. İlk çağlarda uygulanan doğrudan demokrasi yöntemleri, günümüzde uygulanabilirliğini büyük oranda yitirmiş ve demokrasi ile yönetilen ülkelerde temsili demokrasi yöntemleri yaygın olarak uygulanır hale gelmiştir.

Halkın yerelde karar alma süreçlerine katılım düzeyinin artması, yerel yönetimlerin demokratikleşme düzeylerinin de artmasını sağlayabilecektir. Bu bakımdan günümüzde yalnızca seçimlerde oy kullanmanın yerel yönetimlerde demokratikleşmeyi ve halkın siyasal katılımını sağlayamayacağı söylenebilir. Demokratik ülkelerde seçimlere katılan her siyasi partinin yüksek oy almak suretiyle rakiplerine üstünlük sağlama ve yönetim hakkını elde etme amac1 bulunmaktadır. Bu amaca yönelik olarak halkın taleplerini en iyi kendilerinin karşılayabileceği iddiasından hareketle çeşitli vaatlerde bulunmakta ve politikalarını açıklamaktadırlar. Halkın özellikle yerelde kendilerini ilgilendiren kararlarda kendilerine danışılması ve karar sürecine dahil edilmesi talebinin bulunduğu bilinen bir gerçektir. Bu taleplerin yönetime geldikleri takdirde siyasi partiler tarafından nasıl karşılanacağ seçimlerden önce kamuoyuna açıklanmaktadır. Bu açıklamayı siyasi partiler, seçimlerden önce hazırladıkları seçim beyannamesi, seçim bildirgesi, seçim manifestosu, seçim bildirisi, vizyon belgesi gibi çeşitli isimler altındaki metinleri yayımlamak suretiyle gerçekleştirmektedirler. Bu metinler aracılığıyla siyasi partiler sağlıktan eğitime, savunmadan ekonomiye, demokratik katılımdan sosyal politikaya dek çok farklı konularda uygulayacakları politikaları halkla paylaşmış olmaktadırlar. Siyasi partilerin seçilmeleri durumunda uygulamayı vaat ettikleri politikaların özellikle yerel düzeyde seçmenlerin kararları üzerinde etkili olduğunu söyleyebiliriz. Çünkü genel seçimler ve yerel seçimlerde siyasi partilerin aldığı oy oranlarına baktığımızda farklı sonuçların ortaya çıktığını görmek mümkündür. Temsili demokrasilerde halkın yönetime doğrudan katılımına izin veren ve bu özelliği dolayısıyla demokrasinin gelişimine önemli katkılar sağlayan yerel yönetimler, halkın demokratik taleplerinin karşılanabildiği yapılardır. Halkın talebi doğrultusunda hareket etmiş olmak üzere Türkiye'de siyasi partiler, demokratik katılım politikalarını yerel seçimlerde ön plana çıarmakta ve bu politikalara, halkı etkilemek ve oylarını artırmak amacıyla seçim beyannamelerinde yer vermektedirler.

Bu çalışmanın konusu Türkiye'de yerel seçimlere katılan siyasi partilerin demokratik katılım politikalarıdır. Çalışmada nitel araştırma yöntemlerinden doküman incelemesi yöntemi kullanılmıştır. Çalışmanın konusu kapsamında yazılı ve görsel materyallerin yanında, siyasi partilerin resmi web siteleri de kapsamlı bir şekilde taranmıştır. Veriler, yerel seçimler öncesinde siyasi partilerin seçim beyannamesi, seçim bildirgesi, seçim manifestosu, seçim bildirisi, vizyon belgesi gibi çeşitli isimler altında yayımladıkları belgelerden sağlanmıştır. Bu bağlamda siyasi partilerin seçimleri kazanmaları ve göreve gelmeleri durumunda yerel katılıma yönelik olarak uygulamayı vaat ettikleri politikalar incelenmiştir. Araştırmaya, 30 Mart 2014 ve 31 Mart 2019 yerel seçimlerine katılan ve en çok oyu alan 5 siyasi parti dahil edilmiştir. Buna göre sırası ile Adalet ve Kalkınma Partisi (Ak Parti), Cumhuriyet Halk Partisi (Chp), Milliyetçi Hareket Partisi (Mhp), Halkların Demokrasi Partisi (Hdp) ve İyi Parti’nin yerel seçimlerden önce kamuoyuna açıkladıkları seçim beyannameleri üzerinde inceleme yapılmıştır. 30 Mart 2014 yerel seçimlerine katılmayan (kuruluş tarihinden önce) İyi Parti, yalnızca 31 Mart 2019 tarihli yerel seçimlerde 
incelemeye dâhil edilebilmiştir. Araştırmada tarafsılılı ölçütüne bağlı kalınarak yerel seçimlerden önce yayımlanan belgelerde "katılım, yerel katılım ve demokratik katılım" kavramları taranmış, nesnel ve tutarlı sonuçlara ulaşılmıştır.

\section{Demokrasi Kavramı ve Demokrasi Modellerinde Katılım Düzeyleri}

Kökeni itibariyle Latince olan demokrasi kavram1, Eski Yunancada "halk-yurttaş" anlamına karşılık gelen "demos" ve "egemenlik-iktidar" anlamına karşılık gelen "kratos" sözcüklerinin birleşiminden oluşmaktadır (Gözübüyük, 2013, s. 22). Sözlük anlamına bakıldığında demokrasinin "halkın kendi kendini yönetme biçimi" şeklinde tanımlandığı görülebilmektedir (Ejder, 2016, s.190). Buna göre en basit şekilde demokrasi, halkın egemenliği yâda halkın iktidarı olarak tanımlanabilmektedir. Tanımda ifade edilen halk kavramı ise, herhangi bir ayrım gözetilmeden herkesin eşit siyasal haklara sahip olduğu kişiler topluluğunu kapsamaktadır. ABD'de köleliği kaldıran başkan olarak da bilinen Abraham Lincoln demokrasinin; "halkın halk tarafından ve halk için yönetimi" olduğunu ifade etmiştir (Gözler, 2010, s.258; Erdoğan, 2004, s.232). Yönetim şekli tanımlamalarına bakıldığında, egemenliğin kim tarafından kullanıldığının temel belirleyici unsur olduğu görülmektedir. Egemenliğin kullanımı tek kişiye ait olabileceği gibi, bir grup/zümre ya da halkın bütününe de ait olabilmektedir. Bu noktadan hareketle demokrasinin tanımını; egemenliğin kullanımının halka ait olduğu ve halk tarafindan doğrudan kullanıldığı, halktan başka bir gücün ya da halkın üstünde herhangi bir otoritenin olmadığı ve halkın genelinin isteklerini bütünüyle karşılayan bir yönetim şekli olarak tanımlamak mümkündür (Lijphart, 1988, s. 1).

Demokrasinin varlığından, halkın genelini ilgilendiren temel kararları halkın kendisinin alabilmesi veya bu nitelikteki kararları almaya yetkisinin olması durumunda ancak söz edilebilmektedir (Pustu, 2005, s.122). Demokrasi, "kişisel özgürlük, temel haklarda eşitlik, halkın kendisini yöneten memurlar üzerindeki üstünlüğü, toplumsal refah ve adalet" gibi çeşitli değerleri bünyesinde barındırmaktadır (Hill, 1974, s. 23). Temel olarak özgürlük ve eşitlik ilkesine dayalı olan demokrasi, "insan hakları, katılım, temsil, çoğulculuk, sözleşme düzeni” gibi bazı ilkeleri de içeren ve sivil toplumun devletten, belli ölçülerde de olsa ayrıllı̆ını kabul eden bir yönetim şekli” olarak görülmektedir (Yıldırım, 1990, s.9).

Tarihte doğrudan demokrasi uygulamalarının ilk örnekleri M.Ö. 5. yüzyılda Atina sitelerinde görülmektedir. "Site” kavramı ise Rousseau (2018, s.15)'ya göre kenti değil, kenti oluşturan yurttaşları ifade etmektedir. Doğrudan demokrasi uygulamalarında halk, alınacak kararlara yönelik olarak bir araya toplanmakta ve yöneticilere seçimlerini bildirmekteydiler. Ancak doğrudan demokrasinin ilk örnekleri sayılan bu uygulamalarda halkın bütününün katılımı söz konusu değildi. Köleler ve kadınlar karar verme sürecine dâhil edilmemekte ve vatandaşlardan yalnızca belli bir yaşın üstündeki erkekler bu toplantılara katılabilmekteydiler. Atina' da uygulanan bu doğrudan demokrasi yönteminde, tek kişinin sınırsız ve mutlak hakimiyeti ortadan kaldırılmakla birlikte, halkın bütününe söz hakkı verilmemesi, vatandaşlar arasında eşitlik olmaması ve genel oy hakkı sağlanmaması gibi eksiklikler bulunmaktaydı. (Giritli ve Sarmaşık, 1998, s.49; Gözler, 2018, s.115).

Demokrasinin ilk uygulamalarına bakılacak olursa, tanımında ifade edilen "halk" 1 bir ülkede yaşayan tüm bireyleri kapsamadığı ve bu konuda ihtilaf bulunduğu görülebilecektir. Çağdaş demokrasi anlayışında dahi yönetime katılım anlamında (gerekçesi göz ardı edilirse), halkın bir bölümüne hak tanınmadığı bilinmektedir. Demokrasi tanımının unsurlarında ihtilaf bulunduğunu destekler şekilde Spinoza (2009, s. 14) demokrasiyi, yalnızca bir ülkenin yasalarına göre yönetilen (yabancı ülke vatandaşları hariç) özgür vatandaşların (köleler hariç), "yüce mecliste" oy verme hakkı ve kamu görevlerine katılma hakkına sahip "onurlu" bir şekilde (kısıtlı olanlar hariç) yaşadığı düzen olarak adlandırmaktadır. Bu tanımda da görüleceği üzere demokrasinin hâkim olduğu bir toplumsal düzende bazı bireylerin yönetime ilişkin kararlara katılım hakkı bulunmamaktadır. 
Demokrasi halka, yönetim görevi verilen kişileri anayasal düzene uygun bir biçimde değiştirme imkânı veren bir "siyaset sistemi" olarak da tanımlanmaktadır. Sosyal bir araç olarak da görülebilen demokrasi sayesinde, halkın olabildiğince büyük çoğunluğunun, siyasal iktidarın belirlenmesi doğrultusunda katılımı sağlanmakta, halk adına kimlerin karar vereceğinin yine halkın tamamı ya da çoğunluğu tarafından belirlenmesine izin verilmektedir (Lipset,1964, s.25). Azınlığın değil çoğunluğun kararlarda belirleyici oluşu kararlara katılmayan azınlığın mağdur edilebileceği gibi bir durumu akıllara getirebilir. Ancak demokrasinin özünde, hiçbir bireyin ne toplum ne de devlet uğruna feda edilemeyeceği, çoğunluğun kararlarda belirleyici olmasının diğer azınlık üzerinde tahakküm kurma hakkını ona vermediği düşüncesi yatmaktadır (Bilge, 2011, s.56). Fukuyama (1999, s. 58)'ya göre demokrasinin en temel unsuru, halka verilen seçme ve seçilme hakkıdır. Ona göre demokrasi, tüm vatandaşlara siyasal iktidarı belirlemek üzere seçme hakkı vermekte ve aynı zamanda seçilme hakkı da vererek siyasal görevlerde yer alabilmesine olanak sunmaktadır. Bir ülkede demokrasinin olup olmadığını yâda ne ölçüde var olduğunu anlamak için halka seçme ve seçilme hakkının verilip verilmediğine bakmak gereklidir. Bu açıdan bakıldığında siyasal katılım, demokrasinin en temel göstergesi olarak ifade edilebilir. Çitçi (1989, s.18)'ye göre de; günümüzde yerel, ulusal yâda uluslararası düzeyde olmasına bakılmaksızın ne düzeyde olursa olsun "katılma ve temsil"in, demokratik ve etkili yönetimin esas özelliklerinden biri olduğuna yönelik genel bir uzlaşı bulunmaktadır.

Demokrasinin, egemenliğin kullanımını halka vermesi nedeniyle günümüzde artık küresel boyutta diğer siyasal sistemler içinde en çok rağbet edilen, meşru görülen ve en çok kabul gören yönetim sistemi olduğunu söylemek mümkündür. Bunda, elbette ki halkın yönetime katılımının sağlanması ve ülke yönetiminde kendisinin de söz sahibi olma taleplerinin sonucunda elde edilmiş kazanımların payı büyüktür (Lansford, 2007, s .9). Bütün unsurlarıyla bir bütün olarak uygulandığında ideal bir yönetim şekli olduğu da vurgulanan demokrasinin, ilk ortaya çıkışından günümüze farklı birçok modeli de ortaya konulmuştur. Demokrasinin uygulanış1 bakımından "doğrudan, temsili ve katılımcı demokrasi" olmak üzere temel üç modeli aşağıda açıklanmaktadır.

\subsection{Doğrudan Demokrasi Modelinde Katılım Düzeyi}

İdeal demokrasi olarak da adlandırılan doğrudan demokrasi, halkın, yönetimi herhangi bir aracı olmaksızın tamamen elinde bulundurduğu bir demokrasi modelidir. Doğrudan demokraside halk politikanın bizatihi içindedir ve yaşanan sorunların politik olarak çözümünde ya da alınacak kararlarda aracısız söz hakkına sahiptir (Güçyetmez, 2017, s. 483). Bu kararların alınma süreci ise önceki bölümde de anlatıldığ 1 üzere; yasama faaliyetlerini yerine getirmek üzere siyasi kararlara katılım hakkı bulunan bütün vatandaşların bir araya toplanarak oy vermelerini içermektedir. Yasama sürecinin ardından halkın içinden yine halk tarafından yürütme faaliyetlerini yerine getirecek olan kişiler seçilir. Böylece halkın egemenlik hakkı doğrudan doğruya yine halk tarafından kullanmış olmaktadır (Özer, 2016, s. 88). Doğrudan demokraside halka aracı olacak herhangi kişi yâda kurum olmadan halkın kendi kendini yönetmek üzere önemli kararları almak ve bu doğrultuda kanunları yaparak bu kanunları uygulayacak yöneticileri belirlemek suretiyle bir nevi parlamentonun görevi yerine getirilmektedir (Çam, 1995, s. 399). Doğrudan demokrasiyi, diğer demokrasi modellerinden ayıran temel unsurlar yasama sürecine müdahil olup olmama bağlamında ele alınmaktadır. Doğrudan demokrasi sürecinde halkın yasama üyelerini ve yöneticileri seçmesinden ziyade, halkın kendisini ilgilendiren konularda doğrudan doğruya karar verebilmesi yâda düşüncelerini ifade edebilmesi söz konusudur (Altman, 2011, s. 7).

Antik Yunan şehir devletlerinde uygulanan ve ilk demokrasi örneği olarak da bilinen doğrudan demokrasinin, diğer demokrasi modellerinin eleştirilen yönlerini ortadan kaldıran, bir başka deyişle kusursuz demokrasi modeli olduğu düşünülmektedir (Holden, 2007, s.54). Doğrudan demokrasinin uygulanışı iki biçimde gerçekleşmiştir. İlkinde düzenli olarak toplanan tüm halkın yönetime doğrudan katılma hakkına sahip olduğu ve kararların çoğunluğun tercihleri doğrultusunda belirlendiği bir uygulama söz konusuydu. Bu uygulama ile halkın üzerinde başka 
herhangi bir organ bulunmadan doğrudan yönetimi sağlanmaktaydı. İkinci uygulamada ise, sürekli görev yapmayı gerektiren yönetim görevlerine yâda resmi makamlara atanacak kişilerin belirlenmesi seçimle değil sırayla yâda kura yöntemi ile belirlenmekteydi. Böylece halkın tamamı sırası ile yönetimde yer almaktaydı (Heywood, 1997, s. 108).

Halkın katılım düzeyinin en yüksek olduğu demokrasi modeli doğrudan demokrasi modelidir. Ancak ideal yâda kusursuz olarak da adlandırılan bu demokrasi modelinin uygulanması pratikte oldukça zordur. Günümüzde doğrudan demokrasi modelinin yalnızca İsviçre'ye bağlı "Glaris Kantonu" isimli küçük bir dağ kantonunda ve dört yarım-kantonunda uygulandığı bilinmektedir. Bu kantonlar; "Aşağı Unterwald" ve "Yukarı Unterwald" ile "İç Appenzell" ve "D1ş Appenzell”dir (Gözler, 2013, s. 103-104). Belki az nüfuslu ve yüzölçümü küçük ülkelerde uygulanabilme ihtimali olsa da, böyle bir yasama sürecini işletmek üzere insanları bir araya toplamak günümüz ölçeğindeki ülkelerin neredeyse tamamında imkânsız gibi görünmektedir. Ayrıca yaşadığımız çağda hızıı kararlar almanın kimi zaman hayati önem taşıdığı da düşünülecek olursa, doğrudan demokrasi, günümüz koşullarında gerek fiziksel gerekse teknik anlamda uygulanması imkânsız bir ideal olarak karşımıza çıkmaktadır.

\subsection{Temsili Demokrasi Modelinde Katılım Düzeyi}

Demokrasinin ilk örneklerinin görüldüğü doğrudan demokrasi modelinin, diğer demokrasi modellerine kıyasla daha eski bir tarihi bulunmakla birlikte, tarihsel süreç içerisinde gerek devletlerin gerekse toplumların yapısal değişimi ve dönüşümü sonrasında işlerliğini yitiren bir model halini almıştır. Doğrudan demokrasi modelinin uygulanamamasına ilişkin bazı sorunlar demokrasinin yeni bir modelinin doğmasına neden olmuştur. Böylece vatandaşlara seçimlere katılarak temsilcilerini seçmek suretiyle kendilerini yönetme hakkı sağlayan temsili demokrasi modeli ortaya çıkmıştır (Saray, 1999, s. 1). Demokrasiden vazgeçmeden halkın yine kendi kendini yönetmesi olarak kabul edilen bir model ortaya konulması gerekliliği, temsili demokrasiyi gündeme getirmiştir. Temsili demokrasiye göre, halk adına karar verebilecek kişilere yetki vermek üzere, halkı temsil ve halka hükümet edebilecek ölçüde kabiliyetli kişiler, belli bir seçim sürecinin ardından belirlenmektedir (Armaoğlu,1953, s. 5).

Temsili demokrasinin ana unsurunun ne olduğuna baktığımızda "başkaları adına irade ortaya koyarak işlem yapabilme yetkisini" ve temsilci / temsil edilen arasındaki ilişkinin derecesini ve boyutunu belirlemesi nedeniyle de önemli olan "temsil" kavramı göze çarpmaktadır (Nacak, 2014, s.196). Halk ile temsilciler arasındaki bağ ise seçimler yoluyla kurulmaktadır (Ökmen, 2005, s.40). Seçimler temsil yetkisini temsilcilere sağlayan bir başka deyişle, yetkinin oluşmasına aracılık eden ve halkın siyasal haklarını kullanmasına zemin oluşturan oldukça önemli siyasal bir süreçtir.

Temsili demokrasi, doğrudan demokrasinin eleştirilen ve uygulamada sıkıntı oluşturan yönlerini ortadan kaldırması nedeniyle günümüzde demokrasinin uygulandığı ülkelerde tercih edilmektedir. Temsili demokrasi modeli ile daha geniş halk kitlelerine yöneticileri seçme hakkı tanınarak yönetime katılım imkânı sağlanabilmektedir. Temsili demokrasi modeline göre temsil edenlere temsil yetkisinin verilmesi çoğunluğun tercihi esasına dayanmaktadır. Doğrudan demokrasi modelinde pek mümkün olamayan geniş halk kitlelerinin yönetime katılımı, temsili demokrasi modeli ile sağlanabilmekte, ayrıca çoğunluğun iradesi ortaya konularak kararlar bu irade doğrultusunda verilebilmektedir (Mouffe, 2002, s. 29). Çoğunluğun oranının ne olacağı, bir başka deyişle seçime katılan halkın ne kadarının tercihinin temsil edecekleri seçmeye yeteceği, yapılan seçimin niteliğine göre değişebilmektedir. Seçimler yoluyla temsilcilerin seçilmesinin aynı zamanda bazı sorunları da doğurduğu söylenebilmektedir. Bu sorunların başında seçimlerin belli bir zaman aralığında yapılması ve halkın seçim yapmaktan öteye demokrasi sürecinin herhangi bir aşamasında rol alamaması gelmektedir. Seçimle birlikte egemenlik hakkını temsilcilere devreden halkın bir dahaki seçime dek "pasif" bir rol üstlenmesi temsili demokrasinin eleştirilen yönleri olarak karşımıza çıkmaktadır (Çam, 1999, s. 263-264). 
En basit anlamda, bir ülkede yaşayan vatandaşların kendi belirledikleri ve egemenlik haklarını kullanma yetkisini verdikleri temsilciler aracılığıyla yönetimini ifade eden temsili demokrasinin, başta küreselleşme olmak üzere çeşitli nedenlerle günümüzde ideal demokrasiyi sağlayamadığı ve bir kriz içinde olduğu da söylenebilmektedir. Küreselleşme, bir ülkeyi ilgilendiren bütün kararların yalnızca o ülke içinde alınamadığı, bazı kararların uluslararası düzeyde alındığı sonucunu doğurmaktadır. Bu ise halkın kendini ilgilendiren kararlara katılımını imkânsız hale getirmektedir (Tekeli, 2004, s. 3).

Temsili demokrasi modelinin, ideal demokrasiye ulaşma yâda bir başka deyişle değişen koşullara rağmen günümüz toplumlarında demokrasinin uygulanabilirliğini sağlama gayretinin bir göstergesi olduğunu söyleyebiliriz. Temsili demokrasi aynı zamanda, demokrasinin doğal haliyle uygulanmasını zorlaştıran günümüz şartları ile mücadele ederek, demokrasiyi yaşatma imkânını da günümüz toplumlarına sağlamaktadır. Temsili demokrasi ile siyasal haklar bakımından kısıtlı olmayan her vatandaş seçimlere katılarak seçme ve seçilme imkânına kavuşmaktadır. Bu anlamda önemli bir aracılık rolü bulunmakta ancak karar süreçlerine doğrudan demokrasi modelinde olduğu kadar yüksek düzeyde katılım sağlanamamaktadır.

\subsection{Katılımcı Demokrasi Modelinde Katılım Düzeyi}

Temsili demokrasinin yönetimde halkın egemenliğini tam olarak sağlamadığı düşüncesi, katılımcı demokrasiyi gündeme getirmiştir. Katılımcı demokrasi modelinin ortaya çıkışının sebepleri arasında, temsili demokrasi modelinin bazı yönlerden eksik kalışı ve halkın demokratik ihtiyaçlarına cevap verememesi gösterilmektedir (Kocaoğlu, 2014, s.3). Temsili demokrasi modelinin günümüz toplumlarının ihtiyaçlarına cevap vermekte yetersiz kaldığı ve vatandaşların uygulamalara yabancılaştıkları, bundan dolayı da uygulanmasının halkı demokrasiye yaklaştırmadığı için bir meşruiyet krizi yaşadığı söylenebilmektedir (Nacak, 2014, s.202). Hatta kimilerine göre temsili demokrasi, halkı doğrudan demokrasiden uzaklaştıran ve temsilcilerin tahakkümüne yol açan, halkın seçim dönemlerinde oy kullanmanın dışında herhangi bir söz hakkının bulunmadığı bir sistem olarak görülmektedir. Rousseau (2018)'ya göre halkın kendi kendini yönetme hakkı hiçbir şekilde başkalarına devredilemez. Halkın bu hakkını başkalarına devretmesi, özgürlüğünü kaybetmesi anlamına gelmektedir. Katılımcı demokrasi en genel tanımıyla; temsili demokrasi modelini doğuran bütün koşulları dikkate alan ve ayrıca temsil mekanizmasının çalışmasını sağlayan unsurları da kabul eden bir yaklaşımla, doğrudan demokrasinin uygulanması gerekliliğini güçlü bir şekilde dile getirme çabası olarak görülmektedir. Bu çaba doğrultusunda katılımcı demokrasi sayesinde katılımc1 demokratik yapıların oluşturulması amaçlanmaktadır (Yaman, 2017, s. 136).

Temsili demokrasi modelinde, halkın kendi adına karar verecek temsilcilerini "genel ve eşit oyla" yine kendisinin belirlemesi ve kararların temsilcilerce verilmesi söz konusu iken, katılımcı demokrasi modelinde, çeşitli katılım mekanizmaları sayesinde halkın karar sürecine geniş anlamda katılımı söz konusu olmaktadır. Katılımcı demokrasi ile halkın yönetime katılımının olabildiğince yüksek seviyede sağlanması amaçlanmaktadır. Bu amaç doğrultusunda hareket edilerek demokrasinin en temel unsurlarından olan halkın katılımı ve denetimi yerine getirilmiş olmaktadır (Çukurçayır, 2006, s.13). Katılımcı demokrasi modeli ile halk, kendisini yönetecek olan temsilcileri seçmekle birlikte egemenlik hakkını büsbütün temsilcilere devretmemekte ve kendinde saklı tutmaktadır. Bu sayede kendisini yöneten temsilcileri yalnızca seçimlerde değil, seçim süreçlerinin dışında da sürekli denetleyebilmekte, kimi zaman da kararlara katılımı ile yönetim süreçlerini doğrudan yâda dolaylı olarak etkileyebilmektedir (Küçükağa, 1995, s. 15-17). Katılımcı demokrasi modelinde halk katılımının yalnızca seçimlerde oy kullanarak temsilcilerin seçimine katılımdan ibaret olmaması gerektiği vurgulanmakta ve buna yönelik olarak da karar süreçlerine halkın katılımı sağlanarak ideal demokrasiye ulaşılmaya çalışılmaktadır.

Katılımcı demokrasi, vatandaşların kendilerini etkileyen bütün yönetimsel kararların alınması sürecine çeşitli yollarla etkin bir biçimde katılmalarını ifade etmektedir. Katılımcı 
demokraside esas olan halkın kendi isteği ile harekete geçmesi ve herhangi bir etki altında kalmaksızın kararlara katılmasıdır (Sartori,1993, s. 124-125). Bu şekilde bir katılımla, yalnızca temsilcileri seçmek üzere oy kullanmaya dayalı olan, karar verme süreçlerinde sadece temsilcilerin hâkimiyetinin söz konusu olduğu bir iradenin değil; çeşitli mekanizmalar yoluyla halkın doğrudan kendi iradesinin ortaya konulması sağlanabilmektedir. Halk iradesinin doğrudan yönetime yansıması, özellikle hemşehrilik anlayışının hakim olduğu yerel yönetim birimlerinde varlı̆̆ını göstermekte ve yerel yönetimlerde daha etkin uygulanabilmektedir. Katılımcı demokrasi modelinin yerel yönetimlerde etkin uygulanabilmesinin başlıca nedeni olarak ise, yerel yönetimlerin hemşehrilere daha yakın oluşu bu nedenle kolayca ulaşılabilmesi ve örgütsel yapı olarak da katılımın sağlanabilmesine uygun yönetsel birimler olması gösterilmektedir (Kocaoğlu, 2014, s.4). Katılımcı demokrasi; kişilerin kendileri için alınacak kararlara yalnızca seçimlerde değil karar alma süreçlerinin birçok aşamasında farklı yol ve yöntemler kullanılarak katılımını sağlaması ve bu katılımın halkı eğitici işlevi de bulunması nedeniyle temsili demokrasiden olumlu yönde ayrışmaktadır (Çukurçayır, 2006, s. 28).

Demokrasi modelleri arasında en ideal olan ve ulaşılması arzulananın doğrudan demokrasi modeli olduğu görülmektedir. Ancak günümüzde çeşitli nedenlerle uygulanmasının imkânsız olduğu kabul edilmektedir. Temsili demokrasi modeli ise geniş kitlelerin seçimler yoluyla katılımını sağlamakta ancak bu katılım, temsilci seçiminden öteye yönetime katılım anlamında halka demokratik bir hak sağlamamaktadır. Katılımcı demokrasi modeli ise, hem temsili demokrasi modelinin uygulanarak geniş kitlelere kendilerini yönetecek olanları seçme imkanının tanındığı, hem de karar süreçlerine doğrudan katılımın yüksek düzeyde sağlandığı bir model olarak karşımıza çıkmaktadır. Günümüz şartlarında ideal demokrasiye en yakın olduğu söylenebilen katılımcı demokrasi modeli, özellikle yerel yönetimlerde uygulanabilirliğinin yükssek oluşu ve yerel katılımı sağlaması nedeniyle yerel demokrasinin güçlenmesi için önemli bir araçtır.

\section{Yerel Demokrasi ve Yerel Katılım}

Yerel yönetimler, yürütme ve karar organları yerel halk tarafından seçilen, yerel halkın ortak ihtiyaçlarını karşılamak üzere yerel nitelikte çeşitli mal veya hizmetleri sağlamak amacıyla kurulan, yerel örgütlenmeler olarak tanımlanabilmektedir. Buna göre yerel yönetimlerin varlık nedeninin, yerel halkın ihtiyacı olan yerel nitelikli bazı mal yâda hizmetlerin sunulması ve yönetimlerin demokratikleştirilmesi olduğunu söylemek mümkündür (Oktay ve Pekküçükşen: 2009, s. 173). Yerel yönetimlerin, halkın mal ve hizmetleri kullanmasında en tabi hakkı olan özgürlügü, hizmetlerin sunumunda etkinliği ve demokratik katılımı sağlamak üzere temel olarak üç amacı bulunmaktadır. Günümüzde halkın yerel yönetimlerden talebi de bu doğrultuda olmaktadır. Dolayısıyla özgürlük, etkinlik ve demokratik katılımı sağlama" konusunda yerel yönetimlerin ulaştıkları nokta, bu konuda ne ölçüde başarılı olduklarını göstermesi bakımından önemlidir (Tekeli, 1983, s.3).

Genel olarak yerel demokrasi, demokrasinin yerel boyutta hayata geçirilmesi olarak görülmekle birlikte, birbirinden farklı bazı tanımları da yapılmaktadır. Görmez (1997, s. 70) yerel demokrasinin, "demokrasiye dair değerlerin yerel yönetimlerde de geçerli kılınması" olduğunu belirtmektedir. Hill (1974, s. 71)'a göre ise yerel demokrasi; halkı doğrudan ilgilendiren ve halkın yerel gündeminde önemli yer tutan somut bazı sorunların, demokratik ilke ve usullere göre tartışılıp karara bağlandığı ve uygulandığı küçük boyutlu bir dünyadır.

Çağdaş demokrasilerde "katılma ve temsil" gibi esas unsurların yerel yönetimlerde kendine hayat alanı bulması, demokrasi-yerel yönetim ilişkisinin güçlenmesine önemli katkılar sağlamaktadır (Görmez, 1993, s. 65). Yerel yönetimler, halkın kolay erişebileceği ve doğrudan iletişim kurabileceği, katılımc1 demokrasinin uygulanmasına müsait yapısal zeminleri olan örgütler olarak karşımıza çıkmaktadır. Yerel yönetimlerin demokratik yapılar olarak nitelendirilmesinin başlıca nedenleri arasında bu yapılarda seçim ve temsil ilkesinin var olması gelmektedir. Merkezi yönetimin taşra örgütlenmesinde yöneticilerin atama yoluyla göreve geldiği 
ve merkezden alınan kararların uygulandığı göz önünde bulundurulursa, karar alma ve kararları uygulayan yürütme organlarının seçim ilkesine dayalı oluşu nedeniyle, yerel yönetimleri demokratik birimler olarak nitelendirmek mümkündür (Görün, 2006, s.162). Yerel yönetimlerde demokrasinin uygulanabilirliği bakımından ortaya konulabilecek bir diğer üstünlük ise, "ölçek ve yüz yüzelik" özelliğidir. Başka bir ifadeyle, temsil ilkesine dayalı olarak yapılan seçimlerin sonucunda halk tarafindan belirlenen yerel meclisler ve temsilciler arasında hem coğrafi hem de toplumsal bakımdan merkezi yönetime göre önemli derecede bir yakınlık bulunmaktadır. $\mathrm{Bu}$ yakınlık ise, yerel yönetimlerde "denetim ve sorumluluk" gibi demokrasinin vazgeçilemez unsurlarının uygulanabilirliğine imkân sunmaktadır (Çitçi, 1998, s.234).

Yerel yönetimlerde demokrasinin temel unsurlarından birisi olarak görülebilen "temsil"in özellikle ülkemizde gerçek anlamda uygulanamadığına yönelik bazı eleştiriler de yapılmaktadır. Bunun gerekçesi olarak temsilcilerin seçimle gelmesi ve seçim yarışına girecekler bakımından bir takım kısıtlayıcı düzenlemelerin olması ve daha iyi temsil edebileceği düşünülen bazı kesimlerin seçim yarışının dışında bırakılması gösterilmektedir. Ülkemiz ölçeğinde ele alındığında yerelde temsil'e aday olanların çoğunlukla "esnaf, oda başkanı veya üyesi, serbest meslek sahibi" gibi yerelde bazı güç gruplarının üyelerinden oluştuğu görülmektedir. Bu durum ise geniş kitlelerin temsili anlamında ve demokrasinin sağlıklı işleyiş̧i açısından sorun oluşturmaktadır (Çitçi, 1989, s. 5). Yerel demokrasinin ilk kez uygulandığ 1 batılı ülkelerde halkın demokratik katılım taleplerinin etkili olduğunu ve halkın yönetim ve demokrasi kültürünün, yerel demokrasinin oluşum sürecini şekillendirdiğini görebilmekteyiz. Yerel demokrasi ile halkın demokratik katılım taleplerine karşl11k verilebilmekte ve geniş halk kitlelerine demokratik katılım olanağ sağlanabilmektedir. $\mathrm{Bu}$ açıdan bakıldığında yerel demokrasinin, genel olarak demokrasiyi güçlendirdiğini ve demokrasi kuramına da önemli katkılar sağladığını söyleyebiliriz (Eryıldız. 1989, s. 7).

Huntington ve Nelson (1976, s. 4-6)'a göre katılım; siyasetçilerin aldığ 1 kararların siyasetçi olmayan vatandaşlarca etkilenme çabasıdır. Bu tanıma göre katılımın, vatandaşların siyasal karar mekanizmalarını etkileyecek doğrultuda yasal veya yasal olmayan her türlü siyasal davranışını kapsadığı görülmektedir. Çok genel ve kapsamlı bir tanımla katılım; kişilerin kendilerini ilgilendiren bazı konularda alınacak herhangi bir karara veya yapılacak düzenlemeye yönelik olarak iş birliği içinde olmalarını ifade etmektedir. Bu kararlar, yerel yönetimler düzeyinde ise genellikle fiziksel çevreye ilişkin tasarımlar, düzenlemeler ve planlamalar şeklinde karşımıza çıkmaktadır (Yalçındağ, 1999, s.49). Tanımda sözü edilen "kişiler" ile seçilerek veya atanarak herhangi örgütsel bir karar verme sürecinde yetkili veya görevli olmayan vatandaşlar anlatılmakta, bir başka deyişle halka vurgu yapılmaktadır (Churchman: 1987, s.113-158).

Katılımın siyasal ve yönetimsel olmak üzere birbiri ile örtüşen iki boyutundan söz edilebilmektedir (Buran, 1995, s.210). Temsilcilerin yâda yöneticilerin seçim yoluyla belirlenmesinde vatandaşların aktif olarak yer alması, katılımın siyasal boyutunu oluşturmaktadır. Siyasal boyutu yönüyle katılım kavramı, vatandaşların siyasal bir hakkı olan seçme hakkını kapsamakta ve vatandaşların seçime katılmalarının yanında, seçtikleri yöneticilerin eylemlerinde belirleyici ve kararlarında etkileyici olma yönünde ortaya koydukları çabaları da ifade etmektedir. Uygulanan siyasal sistemin ve kurumların yapısı, mevcut siyasal kültür, hukuki çerçeve ve sosyoekonomik koşullar katılımın siyasal boyutu üzerinde etkili olan unsurlardır. Bunlar katılım üzerinde etkili olan, katılımın biçim ve düzeyini belirleyici niteliktedirler (Görün, 2006, s. 164). Katılımın yönetimsel boyutu ise, vatandaşı temsilen seçim yoluyla göreve gelmiş yöneticilerin karar alma süreçlerinde tek taraflı hareket etmelerinden öte, karar sürecine vatandaşların ve sivil toplum kuruluşlarının da dahil edilmesini ifade etmektedir. Bu anlamda yönetici ile vatandaş arasında ortak bir dilin oluşması ve kararların ortak alınması nedeniyle itirazların ortadan kaldırılması ve kararların hızlı bir şekilde uygulamaya konularak gereksiz zaman kaybının önüne geçilebilmesi sağlanmaktadır.

Katılımın, demokrasiye olan en önemli katkılarından biri de halkın siyasal kültürünü geliştirme ve olumlu yönde değişime uğratarak geniş kitlelere söz hakkı sağlaması olarak 
görülebilir. Halka sağlanan katılım mekanizması ile temsilcileri seçmekten başka bir demokratik faaliyete iştiraki bulunmayan halkın, nesne konumundan çıkarılıp özne konumuna getirildiği bir siyasal ortam oluşturulmaktadır (Vera-Zavala, 2006, s. 20). Bunun yanı sıra katılımın, hem vatandaş açısından hem de vatandaşların oyu ile seçilen yerel yöneticiler açısından bazı yararları bulunmaktadır. Vatandaşın yerel katılım imkânı elde etmesi ile kendini gerçekleştirme ve kendini gerçek anlamda demokrasinin uygulandığı bir sistemin parçası olarak görme gibi yararları olduğu söylenebilir. Bu durum aynı zamanda vatandaşlık ruhunu da besleyen ve vatandaş ile devlet arasındaki bağları güçlendiren bir etki oluşturmaktadır (Barber, 2015, s. 368). Seçilmiş temsilciler açısından ise, denetime açık ve şeffaf bir yönetim ortamında aldıkları siyasal kararların meşruluğunu ve güvenilirliğini artırabilmektedirler (Çukurçayır ve Diğerleri, 2015, s.5). Yerel katılımı, vatandaşların yerel yönetimlerde siyasal yetkiyi ele geçirme yâda kendilerini temsilcilerin yerine koyarak karar alma çabası olarak görmemek gerekir. Vatandaşların katılıma ilişkin talepleri doğrultusundaki eylemleri, kendilerini ilgilendiren kararları etkileme çabasından ibarettir. Demokrasilerde katılımın ilk ve olmazsa olmaz denilebilecek unsuru, vatandaşların seçimlere katılımıdır. Bununla birlikte seçim kampanyasının yürütülmesi faaliyetlerine katılma, siyasal partiye para bağışında bulunma, yapılan etkinliklere katılma, afiş asma, broşür dağıtma gibi davranışlar vatandaşların siyasal katılma davranışları olarak kabul edilmektedir (Huntington ve Nelson, 1976, s. 12-13).

Vatandaşın yerel yönetimlere katılma davranışının yalnızca ego tatmininden ibaret olarak kalabilecek bir yönü de vardır. Çünkü her vatandaşın gerçek anlamda demokratik katılımı özümseyebilecek bilgi birikimi, katılıma olan ilgisi ve yerel yönetimlere bakışı farklı olabilmektedir. Dolayısıyla yerel katılımdan gerek vatandaşların gerekse yerel yöneticilerin yararlanma düzeylerinin, vatandaşların siyasal bilgi düzeyleri, katılıma olan ilgileri ve demokrasiye karşı bakış açıları gibi unsurlara göre değiştiğini söylemek mümkündür (Gabriel, 1983, s.100). Yerel yönetimlere katılımın sağlanması doğrultusunda vatandaşlarda demokrasi bilincinin oluşturulması ve siyasal bilgi düzeylerinin artırılması, bir eğitim sorunu olarak görülebilmektedir. Katılımdan üst düzey yarar elde edebilmek için yerel yönetimlerce vatandaşlara yönelik eğitim verilmesi bu bakımdan önemlidir (Atiker, 2012, s.126).

Yerel demokratik katılım sürecinde halk, yerelde birinci dereceden aldığ 1 hizmetlere yönelik olarak alınan kararlara katılabilmekte ve bu kararların uygulanmasını denetleyebilmektedir. Yerel yönetimler, demokrasinin ülke düzeyine yayılması açısından da çıkış noktaları olarak görülmektedirler. Bu niteliklerinden dolayı yerel yönetimlerin demokrasi ile yakın ilişki içerisinde olmalarının kaçınılmaz olduğunu söyleyebiliriz. Yerel yönetimler, halkın demokrasi kültürüne önemli katkılar sağlayan birimler olduğu gibi, katılıma olanak sağlayan yapılarıyla da yönetimlerin demokratikleşmelerinde önemli rol oynamaktadırlar. Yerel katılım, demokratik yerel yönetimin göstergelerinden biri sayllabilmekle birlikte, yerel yönetimlerin daha denetime açık bir örgütsel yapıya kavuşmalarına ve kurumsallaşmalarına da katkı sağlamaktadır. Yerel yönetimlerde yerel demokrasinin varlığından söz edebilmek için, halkın yerel seçimlerde, referandum ve halkoylamasında oy kullanması, yerel meclislerin karar alma süreçlerinde yer alması, faaliyetleri denetleyebilmesi gibi katılıma dair unsurların varlığını görmenin gerekli olduğu söylenebilir.

Yerel yönetimlere talip olan siyasi partiler seçimleri kazanmaları durumunda uygulayacakları yerel katılıma yönelik politikalarını, seçimlerden önce ortaya koydukları seçim bildirgesi, seçim beyannamesi, seçim manifestosu gibi belgelerle kamuoyuna duyurmaktadırlar. $\mathrm{Bu}$ belgelerin seçim öncesi vaatleri içermesinin yanında, seçimi kazanan partiler için bir sonraki seçimler öncesinde bir performans göstergesi niteliği taşıdığı da söylenebilir. Vaatlerin yerine getirilme düzeyinin halk tarafından yerelde daha kolay takip ve tespit edilebilme imkânının bulunması ise bunu doğrular niteliktedir. 


\section{Yöntem}

Araştırmanın amacı; Türkiye'deki siyasi partilerin yerel katılım politikalarına ilişkin yaklaşımlarını, görüşlerini, politika önerilerini ve vaatlerini yerel seçimlerden önce kamuoyuna açıkladıkları (seçim bildirgeleri, seçim beyannameleri, manifesto, vizyon belgesi gibi) belgelerde yer alan bilgiler çerçevesinde karşılaştırarak benzeyen ve farklılaşan yönlerini ortaya koymaktır. Araştırmada, nitel araştırma yöntemlerinden biri olan betimsel araştırma yöntemi kullanılmıştır.

Araştırmanın evrenini, Türkiye'de 2014 ve 2019 yllı yerel seçimlerine katılan siyasi partiler oluşturmaktadır. Buna göre 2014 yılında 23 siyasi parti, 2019 yılında 12 siyasi partinin seçime katıldığı görülmüştür. Araştırmanın örneklemini ise 2014 ve 2019 yılı yerel seçimlerinde en yüksek oyu alan 5 parti oluşturmaktadır. Bu partiler ise; Adalet ve Kalkınma Partisi (Akp), Cumhuriyet Halk Partisi (Chp), Milliyetçi Hareket Partisi (Mhp), Halkların Demokratik Partisi (Hdp) ve İyi Parti'dir. Bağımsızlar her iki seçimde ve 2014 seçimlerine katılmadığı için İyi Parti (parti kuruluş tarihinden önce) bu seçimde değerlendirmeye alınmamıştır.

Araştırmada veri toplama aracı olarak doküman incelemesi tekniği kullanılmış olup, partilerin kamuoyuna açıkladıkları ve ulaşılabilen her türlü yazılı ve görsel materyaller incelenmiştir. Ayrıca partilerin resmi web siteleri de ayrıntılı olarak taranmıştır.

Verilerin analizi 2014 ve 2019 yerel seçimlerinde en yüksek oyu alan örnekleme dahil partilerin (Akp, Chp, Mhp, Hdp ve İyi Parti) yerel katılım politikalarına ilişkin vaatleri, politika önerileri, görüşleri ve konuya ilişkin yaklaşımları "katılım" teması temel alınarak incelenmiş; farklılaşan, benzeyen ve eksik bulunan yönleri yorumlanmıştır.

\section{Bulgular}

Araştırma konusu kapsamında yazılı ve görsel materyallerin yanında, siyasi partilerin resmi web siteleri de kapsamlı bir şekilde taranmıştır. Bulgular, yerel seçimler öncesinde siyasi partilerin seçim beyannamesi, seçim bildirgesi, seçim manifestosu, seçim bildirisi, vizyon belgesi gibi çeşitli isimler altında yayımladıkları belgelerden sağlanmıştır. Araştırmaya, 30 Mart 2014 ve 31 Mart 2019 yerel seçimlerine katılan ve en çok oyu alan 5 siyasi parti dahil edilmiştir. Buna göre sırası ile Adalet ve Kalkınma Partisi (Ak Parti), Cumhuriyet Halk Partisi (Chp), Milliyetçi Hareket Partisi (Mhp), Halkların Demokrasi Partisi (Hdp) ve İyi Parti'nin (2014 yerel seçimleri hariç) her iki yerel seçimden önce kamuoyuna açıkladıkları seçim beyannameleri incelenmiştir.

\subsection{Adalet ve Kalkınma Partisi (Ak Parti)}

\subsubsection{Mart 2014 Yerel Seçimleri}

Tablo 1. 2014 yılı yerel seçimlerinde Ak Parti'nin yerel katılım politikaları

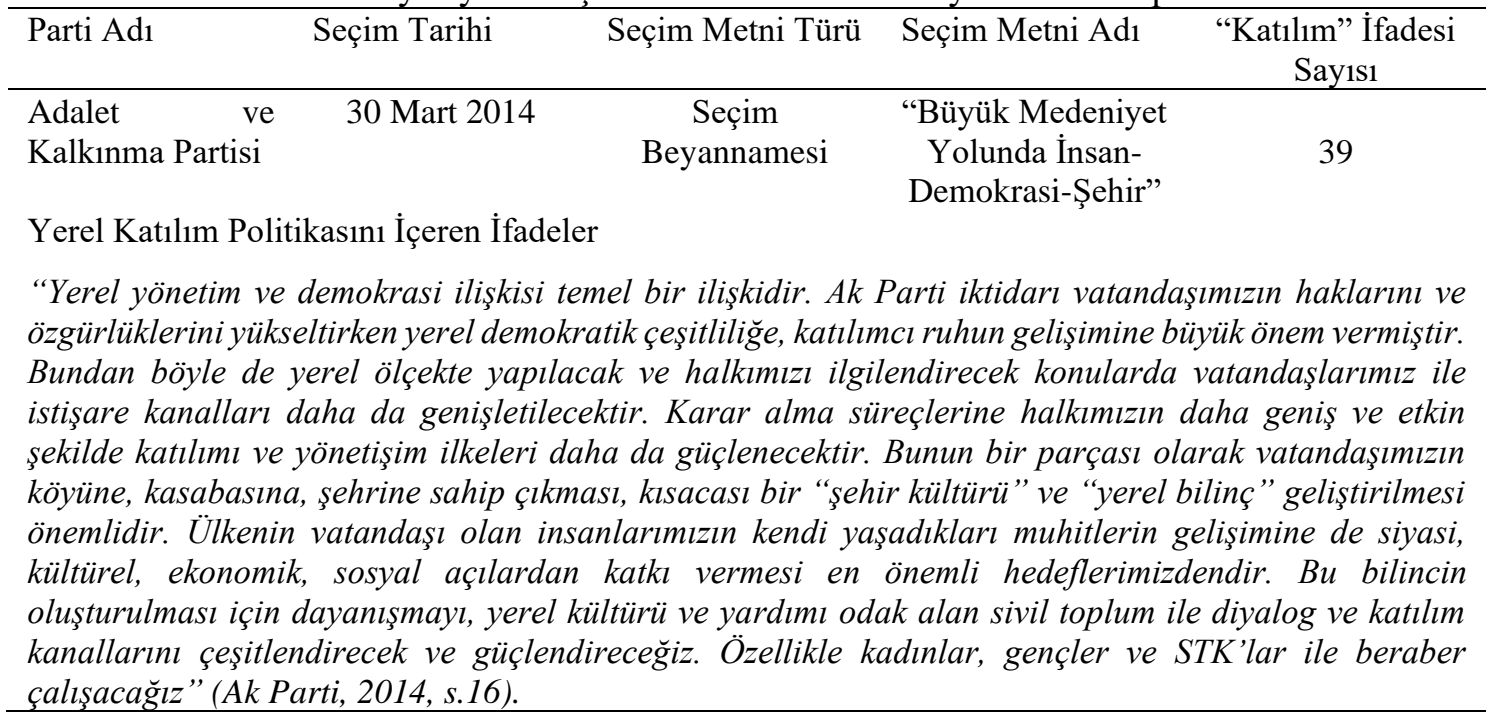


Ak Parti 2014 Yerel seçimleri öncesinde "Büyük Medeniyet Yolunda İnsan-DemokrasiŞehir" adıyla seçim vaatlerini altı başlık altında sıraladığı yüz sayfadan oluşan bir kitap halinde seçim beyannamesi yayımlamıştır. Beyannamede "katılım" sözcüğünün 39 kez yazılı olduğu görülmektedir. Beyannamenin ikinci başlığı "katılımcı belediyecilik" olarak belirlenmiş ve beyannamede konuya on altı sayfada yer verilmiştir.

Beyannamede, Ak Parti'nin katılımcı belediyecilik anlayışının temel unsurları; saydamlık, hesap verebilirlik ve demokratik bir yapıda kamusal değer oluşturmak olarak sıralanmıştır. Yerel yönetimlerin rol ve sorumluluklarının artırılacağı belirtilerek;

- "Yerindelik ilkesi gereğince hizmetin vatandaşlara en yakın birimlerce sunulmasl,

- Sunulan hizmetlerle ilgili karar süreçlerine vatandaşların katkısinin sağlanması,

- Toplumsal tercihlerle uyumlu hizmetlerin sunulması,

- Sunulan kamu hizmetlerinin ülke genelinde adil bir şekilde dă̆llımının sağlanması,

- Bölgesel ve yerel gelişmişlik farklarinin giderilmesi,

- Şeffaflık ve hesap verebilirliğin güçlendirilmesi" ilkelerinin takip edileceği vurgulanmıştır (Ak Parti, 2014, s. 17).

Ak Parti yerel seçimleri kazanması durumunda yerel katılımı geliştirmek üzere daha çok ve farklı yöntemleri kullanacağını vaat etmiştir. Yerel hizmetlerin daha hızlı, kolay ve etkili verilebilmesi, halkın rahatı ve zaman tasarrufu açısından internetten verilen hizmetlerin artırılacağı ve hizmet kalitesinin yükseltileceği bu yöntemler arasında sayılmıştır. Bu dönemde, halkın katılımının daha da artırılacağ 1 ve yerel yönetimlerin karar alma süreçlerini ve icraatları saydam bir şekilde takip ederek halkın denetiminin sağlanacağı, mahalle yönetiminin daha katılımcı çalışacak bir şekilde yeniden kurgulanacağı, kent konseylerinin belediyelerden daha özerk hale getirileceği, kurumsallaşmaları için gerekli düzenlemelerin yapılacağı belirtilmiştir.

\subsubsection{Mart 2019 Mahalli İdareler Genel Seçimleri}

Tablo 2. 2019 y1lı yerel seçimlerinde Ak Parti'nin yerel katılım politikaları

\begin{tabular}{lclcc}
\hline Parti Adı & Seçim Tarihi & $\begin{array}{l}\text { Seçim Metni } \\
\text { Türü }\end{array}$ & Seçim Metni Adı & $\begin{array}{c}\text { "Katılım” İfadesi } \\
\text { Sayısı }\end{array}$ \\
\hline Adalet ve & 31 Mart 2019 & Manifesto & “31 Mart 2019 & \\
Kalkınma Partisi & & & Mahalli İdareler & 3 \\
& & & Genel Seçimleri & \\
& & Manifestosu” & \\
Yerel Katılım Politikasını İceren İfadeler & &
\end{tabular}

"Şehir planları konusunda yapılan çalı̧̧malarda ilgili tüm kamu, özel sektör ve sivil toplum temsilcilerinin fikirlerine başvuracak, kararları demokratik katılım süreçlerini işleterek, en geniş uzlaşmayla alacă̆ız. Halkla birlikte yönetim ilkesiyle, belediye faaliyetleriyle ilgili kararlara, şehir sakinlerinin, özellikle de muhtarların ve sivil toplum kuruluşlarının en üst seviyede katılımını temin edeceğiz. Bilhassa, insanların hayatlarını doğrudan ilgilendirecek büyük projelerde, bu istișare yöntemini mutlaka kullanacağız. Belediyemizden hizmet alan vatandaşlarımız için bir "Şehirli Hakları" bildirgesi hazırlayacağız. Belediye sinırları içinde yaşayan herkesin katılımıyla toplanacak Şehir Meclislerinde, önemli kararları ortak akıl ile alacağız. Belediye Meclisi toplantılarının ve belediye ihalelerinin canlı yayın dâhil, herkese açık şekilde yapılması için tüm imkânların kullanılmasını să̆layacă̆ız" (Ak Parti, 2019, s.11-15).

Ak Parti 31 Mart 2019 Mahalli idareler genel seçimleri öncesinde "31 Mart 2019 Mahalli İdareler Genel Seçimleri Manifestosu" adıyla Genel Başkan Recep Tayyip Erdoğan imzalı bir manifesto yayımlamıştır. "Katılım” sözcüğünün 3 kez yer aldığı manifestoda Ak Parti’nin yeni dönemdeki belediyecilik anlayışı ve halka olan taahhütleri 11 başlık altında özetlenmiştir. 


\subsection{Cumhuriyet Halk Partisi (Chp)}

\subsubsection{Mart 2014 Yerel Seçimleri}

Tablo 3.2014 yılı yerel seçimlerinde Chp'nin yerel katılım politikaları

\begin{tabular}{|c|c|c|c|c|}
\hline Parti Ad1 & Seçim Tarihi & $\begin{array}{l}\text { Seçim Metni } \\
\text { Türü }\end{array}$ & Seçim Metni Adı & $\begin{array}{c}\text { "Katılım" Ífadesi } \\
\text { Sayıs1 }\end{array}$ \\
\hline $\begin{array}{l}\text { Cumhuriyet Halk } \\
\text { Partisi }\end{array}$ & 30 Mart 2014 & Seçim Bildirgesi & $\begin{array}{l}\text { "Yerel Seçim } \\
\text { Bildirgesi" }\end{array}$ & 2 \\
\hline $\begin{array}{l}\text { "Belediyeleri hall } \\
\text { halkın katılımcl ve }\end{array}$ & $\begin{array}{l}\text { Izla birlikte } \\
\text { kin olmasinı }\end{array}$ & $\begin{array}{l}\text { ĕgiz. Halkın yar } \\
\text { ăğı." (Chp, } 201\end{array}$ & Ina olan uygula & her aşamas \\
\hline
\end{tabular}

Cumhuriyet Halk Partisi 2014 yerel seçimleri öncesinde "Yerel Seçim Bildirgesi" hazırlamış ancak bunu herhangi bir basılı metin olarak yayımlamamış ve basın açıklaması olarak halka duyurmayı tercih etmiştir. Chp'li belediye başkan adaylarının tamamı, yerel seçim öncesinde halka olan vaatlerini içeren ve "taahhütname" adı verilen bir belgeyi imzalamışlardır. Belgede "katılım" sözcüğüne 2 kez yer verilmiştir. Yerel katılım politikasına ilişkin vaatlerini 30 ilkeden oluşan ve "halkçı yerel yönetim modeli" olarak adlandırılan bir model içinde ifade etmiştir.

\subsubsection{Mart 2019 Mahalli İdareler Genel Seçimleri}

Tablo 4. 2019 yılı yerel seçimlerinde Chp'nin yerel katılım politikaları

\begin{tabular}{|c|c|c|c|c|}
\hline Parti Ad1 & Seçim Tarihi & $\begin{array}{l}\text { Seçim Metni } \\
\text { Türü }\end{array}$ & Seçim Metni Adı & $\begin{array}{c}\text { "Katılım” İfadesi } \\
\text { Sayıs1 }\end{array}$ \\
\hline $\begin{array}{l}\text { Cumhuriyet Halk } \\
\text { Partisi }\end{array}$ & 31 Mart 2019 & Seçim Bildirgesi & $\begin{array}{c}\text { "Huzurlu } \\
\text { Kentlerde } \\
\text { Yaşamak İçin } \\
\text { Halkçı } \\
\text { Belediyecilik" }\end{array}$ & 43 \\
\hline
\end{tabular}

Yerel Katılım Politikasını İçeren İfadeler

- "Ülkemizin içinde bulunduğu merkeziyetçi, halktan kopuk ve otoriter yönetim anlayışına karşı; demokratik ve katılımcı yerel yönetim anlayışı esas olacaktır.

- Kentlerin sorunlarına, yurttaşların politika yapım süreçlerine katılımını sağlayarak; birlikte çözüm üreteceğiz.

- Katılım, uzlaşı ve işbirliği, temel yerel yönetim anlayışımızdır.

- Kentleri, demokratik değerlere, temel insan hak ve özgürlüklerine saygll,; idari ve mali özerkliği geliştiren, yurttaş katılımina dayalı bir anlayış̧ yöneteceğiz.

- Aktif yurttaş katılımı için, tüm yerel yönetim organları ve halk arasında şeffaf ve güçlü iletişim kanalları kuracağız. Yurttaşların bilgi edinme hakkı önündeki tüm engelleri kaldıracağız ve katılımı etkin kilabilmek için yönetim süreçlerini halka açık biçimde gerçekleştireceğiz.

- Kentin geleceğini etkileyecek önemli projeleri, tüm paydaşların ve yöre halkının karar süreçlerine katılımını sağlayarak gerçekleştireceğiz. Hassas durumlarda, projelerin, meslek odalarının, sivil toplum örgütlerinin ve yöre halkının onayından geçmesini sağlayacağız.

- Mümkün olan tüm koşullarda doğrudan demokrasiyi yaşama geçireceğiz. Bunun için, "Mahalle Konseyleri", "Semt Meclisleri" gibi girişimleri teşvik edeceğiz. Bunların karar alma süreçlerine doğrudan katıllmlarını sağlayacak düzenlemeler yapacağız.

- Muhtarlar yerelde karar alma süreçlerinde etkili olacak. Muhtarların, kendi yetki ve sorumluluk alanların ilgilendiren hususlarda, Belediye Meclisi toplantılartna aktif katılmalarına olanak sağlayacağız.

- Muhtarların çă̆ın gereklerine göre hizmet verebilmesi için gerekli altyapının oluşturulmasina katkı sağlayacă̆ız. Bunun için gerekli hizmet binast ve personel desteğini sunacağız" (Chp, 2019). 
Chp 2019 Yerel Seçimlerinden önce "Huzurlu Kentlerde Yaşamak İçin Halkç1 Belediyecilik" adıyla 3 bölüm altında vaatlerini sıraladığı 28 sayfalık bir seçim bildirgesi yayımlamıştır. Bildirgede "katılım” sözcüğü 43 kez yer almıştır. Giriş bölümünde "yerel yönetim anlayışımız, çoğulcu demokrasiyi ve katılımcllğı esas alır" ifadesi ile yerel katılımın önemine vurgu yapılmıştır. Yerel katılım politikasına ilişkin vaatler seçim bildirgesinin ilk bölümünde "Katılımc1 Yerel Yönetimler” başlı̆̆ı altında verilmiştir.

\subsection{Milliyetçi Hareket Partisi (Mhp)}

\subsubsection{Mart 2014 Yerel Seçimleri}

Tablo 5. 2014 y1lı yerel seçimlerinde Mhp'nin yerel katılım politikaları

\begin{tabular}{|c|c|c|c|c|}
\hline Parti Adı & Seçim Tarihi & $\begin{array}{l}\text { Seçim Metni } \\
\text { Türü }\end{array}$ & Seçim Metni Adı & $\begin{array}{c}\text { "Katılım" İfadesi } \\
\text { Sayısı }\end{array}$ \\
\hline $\begin{array}{l}\text { Milliyetçi } \\
\text { Hareket Partisi }\end{array}$ & 30 Mart 2014 & Vizyon Belgesi & $\begin{array}{c}\text { "Üretken } \\
\text { Belediyecilik, } \\
\text { Bütüncül } \\
\text { Yaklaşım, Birlikte } \\
\text { Yönetim" }\end{array}$ & 4 \\
\hline
\end{tabular}

Yerel Katılım Politikasını İçeren İfadeler

"Katılımcllık ilkesi: Demokratik katılımı yerel düzeyde yaygınlaştıran, vatandaşı sadece yönetilen değil yönetimde paydaş olarak gören, hemşehrilik bilincini yerleştiren, uzlaşma kültürünü gelişstiren, tarihi, kültürel, doğal tüm değerlerine sahip çıkan ve bu değerleri zenginleştiren belediyecilik"tir (Mhp, 2013, s.15).

Milliyetçi Hareket Partisi 2014 yerel seçimlerinden önce "Üretken Belediyecilik, Bütüncül Yaklaşım, Birlikte Yönetim" adıyla yerel yönetim vizyonunu ortaya koyan bir vizyon belgesi yayımlamıştır. $\mathrm{Bu}$ vizyon belgesinin temelini oluşturan üç yaklaşımdan "Üretken Belediyecilik", kentlilerin birlikte üretmesi ve birlikte yönetim olarak tanımlanmıştır. Ayrıca "Üretken Belediyeciliğin", bölücülüğe ve ayrımcılığa karş1 geliştirilen önemli ve etkili bir belediyecilik anlayışı olduğu, birlik ve beraberliği güçlendiren hizmette kalite, etkinlik ve sürekliliği sağlayan bir yerel yönetim anlayışı olduğu vurgulanmıştır. "Bütüncül Yaklaşım" ise kent insanının fiziksel, sosyal ve kültürel özelliklerinin bir bütün olarak ele alınmasını ve planlamaların bu doğrultuda yapılmasını ifade etmektedir. Aynı zamanda "Bütüncül Yaklaşımın" halk ile yerel yönetimlerin bütünleşmesini sağlayacağı ve böylece yerel yönetimlere halkın ihtiyaçlarını yakından takip etme imkânı sunacağı da belgede belirtilmiştir. Üçüncü olarak belgede yer verilen "Birlikte Yönetim" yaklaşımında ise temel olarak halk katılımına vurgu yapılmıştır. Buna göre kentin ihtiyaçlarının belirlenmesi ve buna yönelik projelerin uygulanmasında kentlinin algısının önemli olduğu, kentlinin katılımının göz önüne alınacağ 1 ve kentliden gelecek geri bildirimlerin bir gelişim aracı olarak ele alınacağ 1 "Birlikte Yönetim" anlayışını oluşturan unsurlar olarak sıralanmıştır (Mhp, 2013, s. 12).

Vizyon belgesinde; "milliyetçilik, çalışkanlık, adalet, dürüstlük, çağdaşlık, kalkınmacılık, katılımcılık, rekabetçilik ve şeffaflık" olmak üzere dokuz temel ilke esas alınmıştır. Bu ilkelerden "katılımcılık" ilkesine vizyon belgesinde ayrı bir başlık altında yer verilmiştir.

Vizyon belgesinde genel olarak "katılım" sözcüğünün yerine "birlikte yönetim" ifadesi tercih edilmiştir. Bu nedenle belgede "katılım" sözcüğüne 4 kez yer verilmiştir. Esas itibariyle "birlikte yönetim" ifadesinin de yerel katılımı karşıladığ 1 düşünüldüğünde ve belgede birlikte incelendiğinde sayının daha yüksek olduğu görülmektedir.

\subsubsection{Mart 2019 Mahalli İdareler Genel Seçimleri}

31 Mart 2019 Mahalli İdareler Genel Seçimleri 'ne yönelik olarak Mhp tarafindan yayımlanmış olan herhangi bir belgeye rastlanmamıştır. 


\subsection{Halkların Demokratik Partisi (Hdp)}

\subsubsection{Mart 2014 Yerel Seçimleri}

Tablo 6. 2014 yılı yerel seçimlerinde Hdp'nin yerel katılım politikaları

\begin{tabular}{|c|c|c|c|c|}
\hline Parti Ad 1 & Seçim Tarihi & $\begin{array}{l}\text { Seçim Metni } \\
\text { Türü }\end{array}$ & Seçim Metni Adı & $\begin{array}{c}\text { "Katılım" İfadesi } \\
\text { Sayısı }\end{array}$ \\
\hline $\begin{array}{l}\text { Halkların } \\
\text { Demokratik } \\
\text { Partisi }\end{array}$ & 30 Mart 2014 & Seçim Bildirgesi & $\begin{array}{c}\text { "Yerel Yönetim ve } \\
\text { Doğrudan } \\
\text { Demokrasi" }\end{array}$ & 20 \\
\hline
\end{tabular}

Yerel Katılım Politikasını İçeren İfadeler

"HDP, gerçek demokratikleşmeye giden yolun, halkların geleceklerini kendi ellerine almasından geçtiğini savunur ve bunun için mücadele eder. Bu amaca ulaşmak için, halkların; ezilenlerin, yoksunların ve yoksulların yaşamın her alanında söz ve karar sahibi olması; yönetim süreçlerine doğrudan katılması gerektiğini bilir" (Hdp, 2014).

Hdp'nin, 2014 y1lı yerel seçimlerinden önce yayımladığ1 seçim bildirgesinde "halkların yönetime doğrudan katılmasını sağlamak" hedefine vurgu yapılmıştır. "Yerel Yönetim ve Doğrudan Demokrasi" başlığı altında yerel katılım politikalarına yer vermiştir. Bildirgede "katılım" sözcüğü 20 kez yer almıştır.

\subsubsection{Mart 2019 Mahalli İdareler Genel Seçimleri}

Tablo 7. 2019 yılı yerel seçimlerinde Hdp'nin yerel katılım politikaları

\begin{tabular}{|c|c|c|c|c|}
\hline Parti Adı & Seçim Tarihi & $\begin{array}{l}\text { Seçim Metni } \\
\text { Türü }\end{array}$ & Seçim Metni Adı & $\begin{array}{c}\text { "Katılım" İfadesi } \\
\text { Sayıs } 1\end{array}$ \\
\hline $\begin{array}{l}\text { Halklarin } \\
\text { Demokratik } \\
\text { Partisi }\end{array}$ & 31 Mart 2019 & Seçim Bildirgesi & $\begin{array}{l}\text { "2019 Yerel } \\
\text { Yönetimler Seçim } \\
\text { Bildirgesi”" }\end{array}$ & 13 \\
\hline
\end{tabular}

Yerel Katılım Politikasını İçeren İfadeler

"Halk yönetime bizzat ve bilfiil katılacak. Kent Meclisleri, Kent Forumlarl, Mahalle Meclisleri, Köy Meclisleri, Kadın Meclisleri, Gençlik Meclisleri yaygınlaştırllacak. Meclis toplantıları halka açık yapılacak ve demokratik kitle örgütlerinin toplantılara katılımının sağlanacak, Yerel ekonomi bütün toplumsal kesimlerin katılımıyla planlanıp düzenlenecek, bütün toplumsal kesimlerin demokratik ve sosyal örgütlenme ağlarını geliştirmeleri, karar alma ve uygulama süreçlerine katılımları sağlanacak. Genç kadınların istihdamına yönelik özel politikalar geliştirilecek ve üretim süreçlerine katılımları arttırllacak. Yeni imar alanlarının oluşturulmasında ve dönüşüm süreçlerinde kadınların karar alma mekanizmalarına katılımları sağlanacak, ayrıca planlama süreçlerine bütün yurttaşların katılımları sağlanacak" (Hdp, 2019).

Hdp, 2019 yerel seçimlerinden önce "2019 Yerel Yönetimler Seçim Bildirgesi” adıyla seçim vaatlerini ve politikalarını içeren bir belge yayımlamıştır. Bu belgede yerel demokrasiyi, "halkın kendi kimliği ile meclisler, kent konseyleri, platformlar, meslek kuruluşlart ve demokratik kitle örgütlenmeleri ile yönetime katılması ve yaşamı ilgilendiren bütün alanlarda kararlara ortak olması" şeklinde tanımlamıştır. Bildirgede "katılım" sözcüğüne 13 kez yer verilmiştir.

\section{5 İyi Parti (İyi Parti)}

\subsubsection{Mart 2014 Yerel Seçimleri}

30 Mart 2014 Yerel Seçimlerinin, partinin kuruluş tarihinden önce yapılmış bir seçim olması nedeniyle herhangi bir inceleme söz konusu olamamıştır.

\subsubsection{Mart 2019 Mahalli İdareler Genel Seçimleri}


Tablo 8. 2019 yılı yerel seçimlerinde İyi Parti'nin yerel katılım politikaları

\begin{tabular}{|c|c|c|c|c|}
\hline Parti Adı & Seçim Tarihi & Seçim Metni Türü & Seçim Metni Ad1 & $\begin{array}{c}\text { "Katılım" İfadesi } \\
\text { Sayıs1 }\end{array}$ \\
\hline İyi Parti & 31 Mart 2019 & $\begin{array}{l}\text { Seçim } \\
\text { Beyannamesi }\end{array}$ & $\begin{array}{l}\text { "Milletimizle } \\
\text { Sözleşme" }\end{array}$ & 40 \\
\hline
\end{tabular}

Yerel Katılım Politikasını İçeren İfadeler

\begin{abstract}
"Demokratik katıllm, vatandaşa güven ve toplumsal memnuniyet ilkeleri çerçevesinde vatandaşlarımızın hayatın kolaylaştıracağız ve yaşam kalitesini artıracağız. Sürdürülebilir bir refah ve huzur ortamı sağlayacağız, "mutlu millet, güçlü devlet" anlayışııı benimsemiş, katıllmcl, üretken, adaletli, vicdanl,, ahlakl, denetlenebilir, öngörülebilir, güvenilir, modern, dinamik ve halkvyla barışık bir kamu yönetimi düzeni kuracağız. Katılımcı demokrasiye uygun olarak kamu hizmetlerinin sunumu ve gelişilmesine ilişsin süreçlerde "Sürekli IYI'leştirme" yaklaşımını benimseyeceğiz, akademi, sivil toplum ve vatandaşları bu sürece dahil edeceğiz. Katılımcı demokrasiyi işler hale getireceğiz. Belediye Hizmetlerini "katılımcı mekanizmaları" içerecek şekilde yaygınlaştıracağız. Vatandaşların görüş̧lerini iletebileceği ve herhangi bir hizmete ilişkin mini referandumlara oy verebileceği "Sorumlu Katıllmcıllk Mekanizması"nı hayata geçireceğiz" (İyi Parti, 2018).
\end{abstract}

31 Mart 2019 Mahalli İdareler Genel Seçimlerinden önce İyi Parti "Milletimizle Sözleşme" adıyla 132 sayfalık bir seçim beyannamesi yayımlamıştır. Beyannamede "katılım" sözcüğü 40 kez yer almıştır.

\title{
Tartışma
}

Günümüzde halkın siyasal kararlara katılım düzeyleri ülkelerin demokratikleşme düzeylerinin de göstergesi sayılmaktadır. Halkın siyasal katılımından yalnızca seçimlerde oy kullanmak değil, karar süreçlerine doğrudan yâda dolaylı katılımın yanında, alınacak kararları etkileyen her türlü eylem ve davranışının da siyasal katılım olarak anlaşılması gerektiği söylenebilir. Bunu doğrular şekilde Nie ve Verba (1989, s. 1) siyasal katılımı; "hükümet yetkililerinin seçiminde ve seçildikten sonra onların yaptıkları işleri doğrudan ya da dolaylı olarak etkilemek amacıyla vatandaşların giriştikleri yasal eylemler" olarak tanımlamışlardır. Siyasi partiler, halkın katılım taleplerini en iyi şekilde karşılamaya yönelik olarak seçimlerden önce oluşturdukları politikaları halka açıklamakta ve "katılım" konusunu seçim kazanmada önemli bir aracı unsur olarak görmektedirler. Halkın katılımının sağlanmasına en uygun örgütsel yapıların ise yerel yönetimler olduğu bilinmektedir. Bu nedenle halkın katılımını sağlayacak kanalların güçlendirilmesinin katılımcı demokrasinin de güçlenmesini sağlayacağı söylenebilir. Sala (2016)'nın "Yeni Demokrasi Arayışları ve Türkiye'de Yerel Yönetim Politikaları" çalışmasında da buna benzer sonuçlara yer verilmiştir. Çalışmada merkezi yönetimin yerel yönetimler üzerinde idari anlamda önemli ölçüde etkili olduğu ve yerel yönetimlerin mali ve idari yetkilerinin artırılmasının yerel demokrasiyi güçlendireceğine vurgu yapılmıştır.

Yaşadığımız çağa özgü koşullar nedeniyle siyasal kararlara doğrudan katılım zorlaşmış ve doğrudan katılımı olabildiğince yüksek düzeyde sağlamaya aracılık eden kent konseyleri, meslek odaları, sivil toplum kuruluşları gibi demokratik örgütler oluşturulmuştur. Özellikle nüfus yoğunluğunun fazla olduğu yerlerde bu örgütlerin yerel katılım düzeylerini artıran bir aracılık rolü bulunmaktadır. Akıncı (2014) tarafından yapılan "Siyasal Katılım Düzeyleri Üzerine Bir İnceleme" başlıklı çalışmada sivil toplum kuruluşlarının siyasal katılım düzeyleri üzerinde önemli etkileri olduğu görülmüştür. Benzer bir araştırma Görün (2006) tarafindan yapılan "Yerel Demokrasi ve Katılım: İzmir, Konya ve Ağrı İl Genel Meclis Üyeleri Üzerinde Bir Araştırma" başlıklı alan araştırmasıdır. Araştırmaya katılan il genel meclisi üyelerinin \% 88,4'ü "yerel yönetimlerin etkin ve verimli hizmet yapabilmesinde, sivil toplum kuruluşları ile ilişki içinde olmasının gerekli olduğunu" belirtmişlerdir. Kaypak (2012) tarafından yapılan "Yerel Yönetimlerde Katılımcı/Müzakereci Demokrasi Sürecinde Sivil Toplum Kuruluşlarının Önemi” adlı çalışmada ise; yerel demokrasinin temelini STK'ların oluşturduğuna, katılımın salt seçim boyutuyla ele alınmasına dair yaklaşımın STK'lar aracılığı ile aşılacağına yönelik 
değerlendirmelere yer verilmiştir. Kent konseylerinin yerel katılım düzeylerini artıran bir aracılık rolü bulunduğunu doğrular nitelikte sonuçlara ise Gürses (2015) tarafindan yapılan ampirik araştırmada ulaşılmıştır. Araştırmada "Marmara Bölgesi'ndeki kent konseyi yürütme kurulu üyelerinin, kent konseylerinin yerel demokrasiye katk1 sağlayacak bir platform olup olmadığ noktasındaki algılarını belirlemek" amaçlanmış ve "kent konseylerinin yerel demokrasi ve siyasal katılımın hayata geçirilmesinde etkin bir platform olduğu" sonucuna ulaşılmıştır.

Siyasal partiler yerel ve genel seçimlerden önce yayımladıkları belgelerle eğitimden sağlığa, yerel katılımdan sosyal hizmet alanına dek birçok konuda seçilmeleri halinde uygulayacakları politikaları seçmenlere duyurmaktadırlar. Bu politikaların siyasi partilerin kendi ideolojik yaklaşımları çerçevesinde oluşturulduğu söylenebilir. Aynı zamanda oy artırma amacına yönelik olarak propaganda sürecinin bir parçası olan bu uygulama, seçmenler üzerinde özellikle yerel seçimlerde sonucu etkileyebilecek düzeyde etkili olabilmektedir. Siyasi partilerin seçimlerden önce yayımladıkları belgelerde yer verdikleri konulara ilişkin alanyazında yapılmış çalışmalar bulunmaktadır. Gürsoy ve Balcı Karaboğa (2015) tarafından yapılan "Siyasi Partilerin Seçim Bildirgelerinde Eğitim Konusu" başlıklı araştırmada "siyasi partilerin iktidar oldukları takdirde eğitim alanında uygulayacakları politikaları karşılaştırmalı olarak ortaya koymak" amaçlanmıştır. 7 Haziran 2015 tarihindeki “25. Dönem Milletvekili Genel Seçimleri” ne katılan siyasi partilerin evren olarak seçildiği araştırmada, siyasi partilerin eğitime dair tasarı ve vaatlerinde kendi ideolojik yaklaşımlarını ve kimliklerini ifade eden hakim dünya görüşlerinin ön plana çıktığı sonucuna ulaşılmıştır.

Konuya ilişkin çok sayıda çalışma bulunduğu ve farklı boyutlardan konunun araştırıldığ görülmektedir. Ancak seçim öncesi siyasi partilerin ortaya koydukları katılım politikalarının kapsamlı bir şekilde araştırıldığı çalışmaya rastlanamamıştır. Bu bakımdan çalışmanın alana dair bir boşluğu doldurabileceği veya önemli katkı sağlayabileceği düşünülmektedir. Siyasi partilerin seçim kazanmak için eğitimden sağlı̆̆a, ulaşımdan sosyal hizmetlere, kentsel dönüşümden çevre konusuna dek birçok konuda politika ürettikleri ve bunları kamuoyu ile paylaştıkları bilinmektedir. Ancak bu politikalara inanarak oy veren halkın oy verdiği partinin seçimi kazanarak göreve gelmesinden sonra bu politikaları hayata geçirmediğini ve bu politikaların yalnızca kâğıt üzerinde yazılı metinden ibaret olduğunu düşünmesi hayal kırıklığ oluşturmaktadır. $\mathrm{Bu}$ ise halkın, demokrasinin en temel unsurları olan siyasal partilere dolaylı olarak da demokrasiye güven düzeylerini düşürebilmektedir. Konuya ilişkin olarak kapsamlı çalışmalar yapacak araştırmacılara, siyasi partilerin özellikle yerel seçim öncesi vaatlerinde, yerel katılım politikalarının seçimi kazanan partilerce ne ölçüde hayata geçirildiğinin belirlenmesi önerilebilir. Böylece demokrasiye katkı sağlanabilecektir.

\section{Sonuç ve Öneriler}

Demokratik ülkelerde siyasi partiler, halk iradesinin yönetime aktarılması bağlamında demokratikleşmenin kilit taşları olarak görülmektedir. Siyasi partilerin bulunmadığı ya da işlevsizleştiği ülkelerde demokrasiden söz edilemeyeceği gerçeği de bunu doğrular niteliktedir. Demokrasinin ilk ortaya çıktığı dönemlerdeki uygulamaları ile günümüzdeki uygulamaları arasında önemli farklılıklar bulunmaktadır. İdeal demokrasi olarak da adlandırılan doğrudan demokrasi, günümüz koşullarında uygulanabilirliği neredeyse imkânsız hale gelmiş bir demokrasi türü olarak karşımıza çıkmaktadır. Ancak özellikle yerel yönetimlerde halkın yönetime katılma taleplerinin bulunduğu ve siyasi partilerin oy almak için seçim vaatlerinde buna yönelik politikalara yer verdikleri bilinmektedir. Türkiye'de yerel seçimler, genel seçimleri kazanma yolunda önemli bir adım olarak görülmektedir. Yerel seçimleri kazanan partilerin yerel birimlerin yönetiminden kaynaklı gücü elinde bulundurması nedeniyle genel seçimlere diğer partilere kıyasla daha hazırlıklı olduğu ve genel seçimler öncesinde daha etkili bir propaganda süreci geçirdiği söylenebilir. Yerel seçimlerin bu önemli fonksiyonu nedeniyle yerel seçimlere katılan siyasi partiler, oylarını artırma amacı doğrultusunda seçmenleri etkilemeye yönelik bazı uygulamaları hayata geçirmektedirler. Bu uygulamalar kapsamında yerel seçimleri kazanmaları durumunda uygulayacakları politikaları içeren ve beyanname, bildiri, bildirge, manifesto, vizyon 
belgesi v.b isimler altında yayımladıkları belgeleri seçimler öncesinde kamuoyu ile paylaşmaktadırlar.

Çalışma kapsamında incelenen 30 Mart 2014 ve 31 Mart 2019 yerel seçimleri öncesinde yerel seçimlere katılan partilerin hemen hepsinin (MHP'nin 2019 yerel seçimleri hariç) bu belgelerden birini yayımlayarak kamuoyu ile paylaştıkları ve yerel katılım politikalarına ilişkin önemli vaatlerde bulundukları ve belgelerde yerel katılım politikalarına ayrı bir yer ayırdıkları görülmüştür. 2014 yıl1 yerel seçimleri öncesinde kamuoyu ile paylaşılan seçim beyannamesinden elde edilen bulgular 1şığında; Akparti' de alınacak kararlarda halkla istişare yapılması ve halkın fikirlerine başvurulması yönünde bir yerel katılım anlayışının hakim olduğunu söyleyebiliriz. $\mathrm{Bu}$ yolla aynı zamanda yönetişim ilkelerinin güçleneceği, halkın yerel bilinç düzeyinin yükseleceği ve şehir kültürünün gelişeceği kabul edilmektedir. Halk katılımının, yerelde siyasal, kültürel, ekonomik ve sosyal gelişime katkı sağlayacağına ve sivil toplum kuruluşlarının bu konuda önemli aktörler olduğuna vurgu yapılmaktadır. 2019 yılı yerel seçimleri öncesinde ise Akparti'de halk katılımı anlayışının "halka danışma" dan çok halkın doğrudan kararlara katılımı temelinde ele alındığı görülmektedir. Bu anlayış doğrultusunda, daha geniş bir kesimin karar alma sürecine doğrudan katılımının sağlanacağı vaat edilmekte ve geniş bir uzlaşma sonrası kararların alınacağı belirtilmektedir. 2019 yılı seçimleri öncesinde özellikle şehir planları konusunda yapılan çalışmalarda demokratik katılım süreçlerinin işletileceği ve kararların en geniş uzlaşmayla alınacağı vurgulanmaktadır. Bunun en önemli nedenleri arasında, Türkiye'de son yıllarda kentsel dönüşümün hızlanması, dikey mimariden yatay mimari anlayışına dönülmesi ve hak sahipleri tarafindan kentsel planlara yapılan itirazların artması sayılabilir. Ak Parti'nin 2019 yılı yerel seçimleri öncesinde ayrıca şeffaf yerel yönetim ilkesi kapsamında da önemli vaatleri bulunmakta ve bu bağlamda Belediye Meclisi toplantılarının ve belediye ihalelerinin canlı yayın dâhil, herkese açık şekilde yapılması için tüm imkânların kullanılmasının sağlanacağı beyannamede vurgulanmaktadir.

2014 y1lı yerel seçimleri öncesinde "Yerel Seçim Bildirgesi" ile vaatlerini kamuoyuna açıklayan Chp'nin "Halkçı Yerel Yönetim Modeli" olarak adlandırdığı bir model geliştirdiği ve bu model içinde yerel katılım politikasına ilişkin vaatlere yer verdiği görülmektedir. Belediyelerin halkla birlikte yönetileceğine, halkın yararına olan uygulamaların her aşamasında halkın katılımcı ve etkin olmasının sağlanacağına vurgu yapılan bildirgede, izlenecek yöntemlere yönelik ayrıntılı bilgi sunulmamıştır. Chp'nin 2019 yerel seçimleri bildirgesinde yerel katılıma ilişkin politikaların daha kapsamlı ele alındığı ve konuya daha geniş yer verildiği söylenebilir. Ancak bildirgede, yapılacaklara yönelik vaatlerin yanında iktidara yönelik eleştirilerin de bulunduğu görülmektedir. Bunda ana muhalefet partisi olmasının etkisinin ağır bastı̆̆ 1 söylenebilir. Chp'ye göre yerel yönetim birimleri doğrudan demokrasinin uygulanma alanlarıdır. $\mathrm{Bu}$ anlayışla $\mathrm{Chp}$, mahalle konseylerinin ve semt meclislerinin teşvik edileceğini, bunların karar alma süreçlerinde etkin olmasına yönelik düzenlemeler yapılacağını belirtmektedir. Yerel yönetimlerin idari ve mali özerkliği geliştirebilecek yapılar olduğuna vurgu yapılan belgede, önemli projelerin, tüm paydaşların ve yöre halkının karar süreçlerine katılımının sağlanarak gerçekleştirileceğine ve hassas durumlarda projelerin, meslek odaları, sivil toplum örgütleri ve yöre halkının onayı alındıktan sonra hayata geçirileceğine yer verilmiştir.

Mhp'nin 2014 yerel seçimlerinden önce "Üretken Belediyecilik, Bütüncül Yaklaşım, Birlikte Yönetim" adıyla yerel yönetim vizyonunu ortaya koyan vizyon belgesi incelendiğinde, halk katılımının daha bütünsel ve halkı birleştirici bir yapı içinde ele alındığı görülmektedir. Bununla birlikte belgede uygulamaya dönük somut yöntemlerden çok Mhp'nin yerel yönetim algısı ve anlayışını ortaya koyan tanımlayıcı ifadelere yer verilmişsir. Vizyon belgesinde temel alınan dokuz ilkenin partinin kurucusu ve ilk genel başkanı Alparslan TÜRKEŞ'in Dokuz Işık Doktrini ile örtüştügü de göze çarpmaktadır. Bu ilkeler ile Mhp'nin geleneksel ve çağdaş yerel yönetim anlayışını birleştiren bir vizyonu benimsediği söylenebilir. 2019 yılı yerel seçimleri öncesinde ise Mhp tarafından yayımlanan ve kamuoyuna açılanan herhangi bir belgeye 
rastlanmamıştır. Bunun nedenleri arasında yerel seçimlere ülke genelinde birçok yerde Cumhur İttifakı ile girilmiş olmasının etkili olduğu söylenebilir.

Hdp'nin 2014 yılı yerel seçimleri öncesinde yayımladığı belgede, halk katılımına dair somut ifadelerden ziyade demokratikleşme hedeflerine, demokratikleşmenin tanımına, soyut ve ölçülemeyen diğer hedeflere yer verilmektedir. Ayrıca belgede diğer partilerin hiçbirinin kullanmadığı "halklar" şeklindeki çoğul bir ifadenin yalnızca Hdp tarafından kullanıldığı da görülmektedir. Hdp'nin 2019 yerel seçimlerinden önce yayımladığı belgede “meclisler, kent konseyleri, platformlar, meslek kuruluşları ve demokratik kitle örgütlenmelerinin" halk katılımında aracı rolüne vurgu yapılmıştır.

İyi Parti'nin 30 Mart 2014 Yerel Seçimlerinden sonra kurulmuş olması nedeniyle bu seçime ilişkin herhangi bir belge incelemesi söz konusu olamamıştır. 2019 yerel seçimlerinde ise "Milletimizle Sözleşme" adıyla 132 sayfalık bir seçim beyannamesi yayımlanmıştır. Beyanname incelendiğinde yerel seçimlerin kapsamından daha geniş ifadelere yer verildiği görülmektedir. Yerel katılıma yönelik önemli hususların beyannamede ele alınmış olduğu ancak bunların nasıl ve hangi yöntemlerle hayata geçirileceğinin somut bir şekilde ortaya konulmadığı söylenebilir.

Her iki seçim de genel olarak değerlendirildiğinde siyasi partilerin seçimlerden önce yayımladıkları belgelerde yerel katılım konusunu ayrı bir başlık altında ele aldıkları ve yerel katılım konusuna ilişkin hususlara önemli sayılabilecek düzeyde yer verdikleri görülmüştür. Bunun en önemli nedenlerinden birinin halkın kendilerini ilgilendiren yerel kararlara katılma talebi ve siyasi partilerin bu talebi en iyi kendilerinin karşılayacağı vaadi ile oy toplama amaçları olduğu söylenebilir. Belgelerde yerel katılıma ilişkin olarak özellikle muhalefet partilerinin konuya dair somut yöntemlerden çok partilerinin yaklaşımlarını ortaya koyan soyut ifadelere yer verdikleri söylenebilir. Ancak iktidar partisinin bu konuda ayrıştığını, konuya dair anlayışın ortaya konulması ve buna dair vaatlerinin yanında bunların uygulamaya nasıl geçirileceğinin de somut ifadelerle halka aktarıldığı seçim öncesi yayımlanan belgelerde görülmektedir.

Araştırmanın alana önemli katkı sağlayacağı ve konuya ilgi duyan araştırmacılara yol gösterici olacağı umulmaktadır. Ayrıca konunun farklı boyutları ile alan araştırmaları yapılarak incelenmesi önerilmektedir. Özellikle kesitsel ve değerlendirme araştırmaları yapılarak önceki ve sonraki durumlara ilişkin analizlerin yapılmasının alana önemli katkılar sağlayabileceği söylenebilir.

\section{Kaynakça}

Akıncı, S. (2014). Siyasal katılım düzeyleri üzerine bir inceleme. KTÜ Sosyal Bilimler Enstitüsü Sosyal Bilimler Dergisi, (7),34-45.

Ak Parti (2014). Büyük medeniyet yolunda insan-demokrasi-şehir, 30 mart 2014 yerel seçimleri seçim beyannamesi. http://www.akparti.org.tr/media/272121/30-mart-2014-yerel-secimbeyannamesi.pdf (Erişim tarihi: 18-07-2019).

Ak Parti (2019). 31 Mart 2019 mahalli idareler genel seçimleri manifestosu. https://www.akparti.org.tr/media/279203/manifesto_28ocak2019_17-29.pdf (Erişim tarihi: 16-10-2019).

Altman, D. (2011). Direct democracy worldwide. Cambridge: Cambridge University Press.

Armaoğlu, F.(1953). Seçim sistemleri. Ankara: Güney Matbaası.

Atiker, E. (2012). Yerel yönetimlere katılım sorunu. İstanbul Üniversitesi Sosyoloji Dergisi, 3(9), 121-126.

Barber B. (2015) Güçlü demokrasi: Yeni bir çă̆ için katılımcı siyaset. (Beşikçi, M., Çev.). İstanbul: Ayrıntı Yayınları. 
Bilge, M. (2011). Türkiye'de demokrasi kültürü: siyaset ve toplum, Türkiye Sosyal Araştırmalar Dergisi, 15(3),49-60.

Buran, H. (1995). Yönetim yurttaş ilişkileri ve katılmall yönetim, Kamu Yönetimi Sempozyumu Bildirileri, C.1, s. 210, TODAİE Yay., Ankara.

Chp (2014). Yerel seçim bildirgesi, http://www.sosyaldemokratdergi.org/gokhan-gunaydin-chpyerel-secim-bildirgesinin-esaslari/ (Erişim tarihi: 28.10.2019).

Chp (2019). Huzurlu kentlerde yaşamak için halkçı belediyecilik, cumhuriyet halk partisi 2019 yerel seçim bildirgesi, https://chp.azureedge.net/2019-secim-bildirgesi.pdf (Erişim tarihi: 28.10.2019).

Churchman, A. (1987). Can resident participation in neighborhood rehabilitiation programs succeed, (I. Altman ve A. Wandresman (eds.), Neighborhood and Community Environment, Pleniom Press, New York içinde, s. 113-158).

Çam, E. (1995). Siyaset bilimine giriş, Genişletilmiş Dördüncü Basım, İstanbul: Der Yayınları.

Çitçi, O. (1998). Yerel siyaset ve demokrasi/ çoğulculuk/ sivil toplum, sivil toplum için kent, yerel siyaset ve demokrasi seminerleri, İstanbul: Dünya Yerel Yönetim ve Demokrasi Akademisi Yay. (WALD).

Çitçi, O. (1989). Yerel yönetimlerde temsil, Amme İdaresi Dergisi, Ankara: TODAİE Yayın No:226.

Çitçi, O. (1989a). Yerel yönetimlerde temsil -belediye örneği. Ankara: TODAİE Yayınları.

Çukurçayır M.A. (2006). Siyasal katılma ve yerel demokrasi. Konya: Çizgi Kitabevi.

Çukurçayır, P, Eroğlu, Y ve Sağır, A. (2015). Yerel yönetişim, katılım ve kent konseyleri. Yerel Politikalar, O(1), Retrieved from https://dergipark. org.tr/yerelpolitikalar/issue/13661/165280

Ejder, Y. (2016). Hukuk sözlüğ̈̈, (Yenilenmiş 5. Bask1), Ankara: Yetkin Yayınları.

Erdoğan, M. (2004). Anayasal demokrasi. Ankara: Siyasal Kitapevi.

Eryıldız, S. (1989). Yerel yönetimde yeniden yapılanma, Ankara: TÜSES Yayınları.

Fukuyama, F. (1999). Tarihin sonu ve son insan, (Dicleli, Z., Çev.). İstanbul: Gün Yay.

Görmez, K. (1993). Yerel demokrasi ve Türk belediyeciliği. Ankara: Hizmet İş Sendikası Yay.

Görün, M. (2006). Yerel demokrasi ve katılım: İzmir, Konya ve Ağr1 il genel meclis üyeleri üzerinde bir araştırma, Yönetim Bilimleri Dergisi (Journal of Administrative Sciences), $4(2), 159-183$.

Gözler K. (2013), Anayasa hukukuna giriş. 20. baskı, Bursa: Ekin Kitabevi.

Gözler, K. (2010). Anayasa hukukunun genel esasları. Bursa: Ekin Basım Yayın Dağıtım.

Gözler, K. (2018). Anayasa hukukuna giriş genel esaslar ve Türk anayasa hukuku. Güncellenmiş 27. baskı, Bursa: Ekin Basım Yayın Dağıtım.

Gözübüyük. A., Ş. (2013). Anayasa hukuku, anayasa metni ve 11. protokole göre hazırlanmış Avrupa insan hakları sözleşmesi, 19. basım, Ankara: Turhan Kitabevi.

Güçyetmez, M. (2017). Karşılaştırmalı demokrasi modelleri ve hükümet sistemleriyle ilişkisi, Hacettepe Hukuk Fakültesi Dergisi, 7(1), 479-496.

Gürses, F. (2015). Yerel demokrasi ve siyasal katılım: kent konseyleri üzerine ampirik bir araştırma, Paradoks Ekonomi, Sosyoloji, ve Politika Dergisi, 11(2) (özel sayı), 49-68.

Gürsoy, M. ve Balcı Karaboğa, A. (2015). Siyasi partilerin seçim bildirgelerinde eğitim konusu, Route Educational and Social Science Journal Volume, 2(4), 112-140. 
Heywood, A. (2007). Political ldeologies, 4th Ed., Londra: Palgrave Macmillan.

Hdp, (2014). HDP 2014 yerel seçim bildirgesi, https://www.hdp.org.tr/tr/materyaller/secimarsivi/yerel-secim-2014/yerel-secim-bildirgesi/5425 (Erişim tarihi: 02.12.2019).

Hdp, (2019). 2019 yerel yönetimler seçim bildirgesi, https://www.hdp.org.tr/images/UserFiles/Documents/Editor/YerelBildirge2019-Turkce.pdf, (Erişim tarihi: 12.12.2019).

Hill, Dilys M, (1974). Democratic Theory And Local Government, London: Plurabelle Books Ltd.

Holden, Barry (2007). Liberal Demokrasiyi Anlamak, (Hüseyin Bal, Çev.). Ankara: Liberte Yayınları.

Huntington, Samuel P. \& Joan M. Nelson (1976). No easy choise: political participation in developing countries. Harvard University Press.

İyi Parti, (2018). Milletimizle sözleşme, https://iyiparti.org.tr/assets/pdf/secim_beyani.pdf (Erişim tarihi: 12.12.2019).

Kocaoğlu, M. (2014). Katılımcı demokrasi algılaması ve kent konseyleri: kırşehir kent konseyi örneği, Hukuk ve Ikktisat Araştırmaları Dergisi, 6(1) ISSN: $2146-0817$ (Online), http://www.sobiad.org/ejournals/dergi_hia/arsiv/2014_1/mustafa_kocaoglu.pdf (Erişim tarihi: 03.07.2019).

Küçükağa, M. (1995). Türkiye'de ve İslam ülkelerinde demokrasi oyunları. İstanbul: Emre Yayınlar1.

Lansford, T. (2007). Political systems of the world democracy. London: Cavendish Square Publishing,

Lijphart, A. (1988). Çă̆daş demokrasiler, (E. Özbudun ve E. Onulduran, Çev.). Ankara: Demokrasi Vakfı ve Siyasi İlimler Derneği Ortak Yayını.

Lipset, M. S. (1964). Siyasi insan (Mete TUNÇAY, Çev.), Siyasi İlimler Serisi: 8, Ankara: Türk Siyasi İlimler Derneği Yayınları.

Mhp, (2014). Üretken belediyecilik, bütüncül yaklaşım-birlikte yönetim, Ankara: Milliyetçi Hareket Partisi Yerel Yönetimler Başkanlığı, Yayın No:9, https://www.mhp.org.tr/usr_img/mhpweb/kitaplar/uretken_belediyecilik_web.pdf (Erişim tarihi: 28.10.2019).

Mouffe, C. (2002). Demokratik paradoks (A. C. Aşkın, Çev.). Ankara: Epos Yayınları.

Nacak, O. (2014). Temsili demokrasinin sorun alanları ve çözüm noktasında yeni bir model: katılımcı demokrasi, Muğla Sıtkı Koçman Üniversitesi Sosyal Bilimler Enstitüsü Dergisi, 32, 194-214.

Nie H. N. \& Verba, S. (1989). Siyasal katılma, kamuoyu ve oy verme davranışı, (İlter Turan ve Tunçer Karamustafaoğlu, Çev.). Ankara: Siyasi İlimler Türk Derneği Yayınları.

Oktay, E. ve Pekküçükşen, Ş. (2009). Yerel yönetimlerin demokratikleşmesinin bir aracı olarak sivil toplum kuruluşları -Türkiye için kısa bir değerlendirme-, KMU İIBF Dergisi, 16,172-186.

Ökmen, M. (2005). Küresel sistem, demokratikleşme-yerelleşme dinamikleri ve yerel demokrasi. k. görmez (ed.). Küreselleşme ve yerelleşme. Ankara: Odak Yayınları.

Özer, A. (2016). Anayasa hukuku. 7. basım, Ankara: Gazi Yayınları.

Pustu, Y. (2005) Yerel yönetimler ve demokrasi. Sayıştay Dergisi, 57, 121-134.

Rousseau, J., J. (2018) Toplum sözleşmesi, (Vedat Günyol, Çev.). 23. Bask1, İstanbul: İş Bankas1 Kültür Yayınları. 
Sala, B. (2016). Yeni demokrasi arayışları ve Türkiye'de yerel yönetim politikaları. Inssan Ve Toplum Bilimleri Araştırmaları Dergisi, 5(6), 1716-1728.

Saray, M. (1999). Türk devletlerinde meclis (parlamento), demokratik düşünce ve Atatürk. Ankara: Atatürk Araştırma Merkezi Yayınları.

Sartori, G. (1993). Demokrasi teorisine geri dönüş. (Tunçer Karamustafaoğlu ve Mehmet Turhan, Çev.). Ankara: Yetkin Yayıncılık.

Spinoza, B. (2009), Politik inceleme, tractatus politicus, (Murat Erşen, Çev.). 2. Baskı, Ankara: Dost Kitabevi.

Tekeli, İ. (1983). Yerel yönetimlerde demokrasi ve Türkiye'de belediyelerin gelişimi. Amme Idaresi Dergisi, 16(2), 3-22.

Tekeli, İ. (2004). Katılımcı demokrasi, sivil ağlar ve sivil toplum kuruluşları, 15. STK Seтроzуити Bildirisi, http://stk.bilgi.edu.tr/cd/01/doc/okuma_02-2.pdf (Erişim tarihi: 03.07.2019).

Turan, Y., F. (2017). Kat1lımc1 demokrasi: kapsam ve unsurlar. Trakya Üniversitesi İktisadi ve İdari Bilimler Fakültesi Dergisi, 6(2)136-160.

Vera- Zavala, A. (2006). Katılımcı demokrasi (dünyadaki katılımcı demokrasi deneyimleri). (Naile ARAS, Çev.). Ankara: Dipnot Yayınları.

Yalçındağ, S. (1999). Belediyelerde halk katılımı. Türk İdare Dergisi, S. 424, Eylül, http://www.tid.gov.tr/Makaleler/Y\%C4\%B1171-424(1999).pdf. (Erişim tarihi: 16/07/2019).

Yıldırım, S. (1993). Yerel yönetim ve demokrasi: kavramlar, yaklaşımlar. İstanbul: T.C. Başbakanlık TOKİ Başkanlığı ve IULA-EMME.

\section{ETİK ve BİLIMSEL İLKELER SORUMLULUK BEYANI}

$\mathrm{Bu}$ çalışmanın tüm hazırlanma süreçlerinde etik kurallara ve bilimsel atıf gösterme ilkelerine riayet edildiğini yazar(lar) beyan eder. Aksi bir durumun tespiti halinde Afyon Kocatepe Üniversitesi Sosyal Bilimler Dergisi'nin hiçbir sorumluluğu olmayıp, tüm sorumluluk makale yazarlarına aittir. 